\title{
The Impact of Job Quality on Wellbeing: Evidence from Kyrgyzstan
}

\author{
Damir Esenaliev $^{1}$ (D) Neil T. N. Ferguson ${ }^{2}$
}

Accepted: 10 September 2018 / Published online: 9 November 2018

(c) The Author(s) 2018

\begin{abstract}
Income and hours worked are insufficient to measure job quality yet these domains dominate literature aimed at understanding its relationship with wellbeing. More so, literature considering job quality in any manner has an overwhelming tendency to look at advanced economies, despite "decent work" being a key policy aim of many agencies and organisations working in emerging countries. This article tests the validity of the concept of job quality as a determinant of welfare in the developing world by generating four six-component indices using bespoke and unique data collected in Kyrgyzstan. Cross-sectional analysis of the performance of these indices against ones comprising only income and hours worked show no relationship between job quality and wellbeing in the latter case but a strong and positive relationship in the former. Jointly, this shows both the importance of more suitably measuring job quality in all contexts and the importance of policy objectives that aim to stimulate better, as well as more, jobs in the developing world.
\end{abstract}

Keywords Job quality · Decent jobs $\cdot$ Kyrgyzstan $\cdot$ Multidimensional indices $\cdot$ Weighting . Subjective wellbeing $\cdot$ Development economics $\cdot$ Labour economics

JEL Classification I31 J01 J81 $\cdot \mathrm{O} 1$

\section{Introduction}

The typical model of labour market supply defines utility as a trade-off between consumption and leisure time, such that $U_{i}=f\left(C_{i}, L_{i}\right)$. The impact of work on well-being in these models, therefore, boils down to income (which drives consumption) and leisure time (which is enjoyable but comes at the price of foregone consumption). A growing body of work (Clark 2005, 2010; Davoine and Erhel 2006) argues that these two domains, alone, are insufficient to measure job quality. It follows that they may also be insufficient

Neil T. N. Ferguson

ferguson@isdc.org

Damir Esenaliev

esenaliev@sipri.org

1 Stockholm International Peace Research Institute, Signalistgatan 9, 16970 Solna, Sweden

2 International Security and Development Center, Auguststraße 89, 10117 Berlin, Germany 
to measure the relationship between work and wellbeing. Despite this observation, scholarship has tended to focus as much on measuring job quality as on its implications for welfare (Boccuzzo and Gianecchini 2015; Dahl et al. 2009; Leschke et al. 2008; Muñoz de Bustillo et al. 2011; Schokkaert et al. 2009). What research that does focus on this relationship tends to focus on the developed world (Clark 2005, 2015; Drobnič et al. 2010; Gallie 2009; García-Pérez et al. 2017; Gómez-Salcedo et al. 2017; Green 2007; Wallace et al. 2007), meaning that developing and transition countries are seldom studied in any type of job quality analysis and are entirely missing from those using broader definitions of the concept (Goos and Manning 2007; Houseman 1995; Yogo 2011). In addition to the academic knowledge gap implicit in this, the creation of "decent jobs" (as well as "more jobs") is a key aim of many development agencies and international organisations (Ritter and Anker 2002; World Bank 2012) suggesting a subsequent policy gap.

In this article, therefore, we ask three key questions. First of all, we seek to understand the relationship between work and (subjective) wellbeing in a post-transition developing country. Subsequently, we ask whether or not an index of job quality comprised only of income and hours worked is sufficient to measure the relationship between work and welfare in developing/transition contexts. Finally, we test whether or not a broader index, comprised of a range of domains, performs better in determining this relationship. These questions develop from a range of theories that link work and welfare. On the one hand, the effort-reward-imbalance model (Siegrist 1996; Theorell and Karasek 1996) focuses on the (im)balance between the demands of the job and corresponding monetary and status rewards. As rewards (i.e. income), at the cost of effort (i.e. foregone leisure time), drive the relationship, this model may imply that narrower measures are sufficient. By contrast, the job-demands-control model stipulates that giving workers more control at work reduces psychological stress and increases job satisfaction through an opportunity to learn and develop (de Jonge et al. 2000). Such outcomes can, easily, be extrapolated to more general measures of welfare, implying that broader measures capture more than narrow ones. Finally, the person-environment-fit model (Caplan and Harrison 1993) looks at the negative impacts of misfit between job and person. What determines "misfit", and whether it is captured by observable indicators of job quality, however, may imply that neither narrow nor broader measures of observable job quality are sufficient.

To test these hypotheses, we develop a range of differently weighted narrow and broad indices of job quality using bespoke and unique data collected in Kyrgyzstan. In the first round of analyses, we test the relationship between "sub-indices" composed only of wages and hours worked and self-reported life satisfaction. We follow this by repeating this process using broader indices based on the work of Clark (2005). Using cross-sectional OLS and ordered probits we show no significant relationship between the sub-indices and selfreported wellbeing. For the full indices, we find a positive and significant relationship such that higher job quality is associated with greater subjective wellbeing. These results fit with the job-demands-control model, whilst suggesting that reward based models are insufficient to describe the relationship between work and welfare in Kyrgyzstan.

These results are of general interest as they show the limitations that can arise when analyses of job quality are based only on simple indicators of income and hours worked. These findings are relevant to studies focussing on the developed, as well as the developing world, lending support to the notion that suitable definition and measurement of job quality is required. They also make an important contribution to the development and transition literatures as they show that job quality is just as important a component of welfare in these economies as in advanced ones. Finally, we also make a contribution to the so-called "happiness literature". In this literature, work has focussed on understanding the impact of 
Table 1 Means of the working population, wageworkers and non-wageworkers

\begin{tabular}{lllll}
\hline Variables & $(1)$ & $(2)$ & $(3)$ & $(4)$ \\
& Employed & Selfemployed & Wageworkers & Difference \\
\hline Age, years & 38.15 & 39.44 & 37.20 & $2.24^{* * *}$ \\
Male (dummy) & 0.62 & 0.72 & 0.54 & $0.18^{* * *}$ \\
Kyrgyz (dummy) & 0.73 & 0.76 & 0.70 & $0.06^{* * *}$ \\
Urban (dummy) & 0.40 & 0.24 & 0.52 & $-0.28^{* * *}$ \\
Risk attitudes & 5.19 & 5.50 & 4.96 & $0.54^{* * *}$ \\
Life satisfaction & 7.07 & 7.20 & 6.97 & $0.23^{* * *}$ \\
Job satisfaction & 6.95 & 6.71 & 7.11 & $0.40^{* * *}$ \\
\hline
\end{tabular}

Age is calculated as of the end 2013; Kyrgyz is main ethnic group; Urban criteria follows Kyrgyz administrative definition and relates mostly to cities; risk attitudes measured in a scale from 1 (low) to 10 (high); life and job satisfaction are measured in a scale from 0 (low) to 10 (high). More information is in Appendix Table 9

Significant differences are marked by if $* * * p<0.01 ; * * p<0.05 ; * p<0.1$

job quality through a range of domains (Cummins 2000; Diener and Biswas-Diener 2002; Diener and Oishi 2000; Ferrer-i-Carbonell 2005; McBride 2001; Meier and Stutzer 2008; Schoon et al. 2005; Wooden et al. 2009), but has tended to focus exclusively on the developed world. The findings presented here show the relevance of these key concepts in a developing/transition context.

The rest of this article is structured as follows: in Sect. 2, we discuss our data and methods; in Sect. 3 our results; and in Sect. 4, our conclusions.

\section{Data and Methods}

All data used in this study comes from the fourth wave of the Life in Kyrgyzstan Study (LiK) (Brück et al. 2014), which includes a significantly enhanced jobs module, which was inserted on request from the authors. ${ }^{1}$ From the survey we generate a sample of $n=2469$ individuals who are engaged in work for monetary remuneration, either self-employed or as wageworkers. We show summary statistics for these individuals in Table 1, splitting by wageworkers and the self-employed. In our sample, wageworkers are younger than the selfemployed, are more likely to be women (although the workforce as a whole is mostly men) and are more likely to be of Kyrgyz ethnicity. Wageworkers are more likely to live in urban areas and display a higher level of risk aversion (Cramer et al. 2002; Ekelund et al. 2005). Finally, wageworkers exhibit higher job satisfaction but lower self-reported wellbeing.

For each individual, we generate four indices of job quality that build on Clark (2005, 2010). In addition to the five domains suggested by Clark (income; hours worked; job security; interestingness of work; and autonomy) we add job formality ${ }^{2}$ in order to account for one of the major contextual differences in the labour markets between developed and developing

\footnotetext{
1 At present, this expanded jobs section is only available in a single wave of the LiK Study, precluding panel data analysis.

${ }^{2}$ We include job formality as a key domain of interest following the work of (for example) Chen (2007). In this work, a number of key features of informal job contracts, and the adverse outcomes linked to them, are considered. These include a lack of labour law protection for workers; disguised employment relationships;
} 
economies (Yamada 1996). ${ }^{3}$ We proxy job formality for wageworkers by presence of a written contract or "workbook" 4 and for the self-employed by whether or not their business is registered with the Kyrgyz government. Following the literature (Addison and Grosso 1996; Baum-Snow and Neal 2009; Edmonds and Pavcnik 2005; Farber 1998; Leete and Schor 1994; Presser 1999), hours worked is derived as standard from time spent working in the previous week and job security from the time a person has held his or her current position. Questions on income, interestingness of work and job autonomy are asked directly in the survey. In addition to these questions, the survey also asks individuals how important they believe each feature is in determining a "good job". ${ }^{5}$ Following Decancq and Lugo (2013), we index these six domains as follows:

$$
J Q_{j}=w_{1}\left(i_{1} \cdot Y_{j}\right)+w_{2}\left(i_{2} \cdot H_{j}\right)+w_{3}\left(i_{3} \cdot S_{j}\right)+w_{4}\left(i_{4} \cdot F_{j}\right)+w_{5}\left(i_{5} \cdot I_{j}\right)+w_{6}\left(i_{6} \cdot A_{j}\right)
$$

where $w_{i}$ is the weight of each domain; $i_{i}$ is the normalisation identifier; $j$ identifies the individual; and Y, H, S, F, I, and A respectively refer to: income, hours worked, security, formality, interestingness and autonomy. Thus, the quality of a person's job is a function of the weights and normalisations of our six domains of interest and his or her reported status for each domain. It follows that any arbitrary change in the weights could have significant impacts on the measure of job quality and its associated impact on wellbeing. This matches longstanding critiques of the impact of weighting (Boccuzzo and Gianecchini 2015; Schokkaert et al. 2009). We explore this possibility by producing four alternative versions of our indices, each using a different weighting mechanism, which we normalise to a hypothetical maximum of one to ensure comparability across the indices.

First, we take the most common and easiest mechanism used in the literature (Decancq and Lugo 2013) and assume that each domain is equally important. As such, the weight of each domain is set equal to that of the others. As we have six domains and normalise to one, each domain is then weighted with the value of 0.167 . We denote this Index 1 . For Indices 2, 3 and 4, we make use of the questions asking how important different features of a job are in determining whether or not it is "good", which are all measured on a Likert scale running from 1 (least important) to 5 (most important). In Index 2, we generate the

Footnote 2 (continued)

and poorly defined hierarchies and responsibilities. In this regard, we view the inclusion of job formality as necessary in the discussion of job quality in the developing world, given the extent of informality in such economies. As per Chen (2007), we note that a number of our other domains might interact positively with informality. For example, it is possible that informal jobs exhibit higher levels of autonomy and income than comparable formal jobs. In turn, many informal jobs in our data exhibit a higher "quality" than many formal ones. Our guiding principle in suggesting that informality interacts negatively with job quality, therefore, is not designed to imply that all informal jobs are "bad" and that all formal jobs are "good". Rather, that for two jobs that exhibit the same levels of all five other domains, the formal job should be of higher quality than the informal job, due to the protections it offers.

3 We note that another domain of interest, particularly in the developed world, relates to work-life balance (Gallie 2013). Due to the structure of the Kyrgyz economy and, in particular, the lack of a service sector, priors suggest very little variation in this regard across the sample. Consequently, this information was not included in the survey.

4 The Kyrgyz workbook stems from the country's time as a Soviet Republic and is a record of employment, holding information on the current employment status and place of employment of an individual, which in effect acts as a written contract.

5 These questions ask: "Thinking about a good job for yourself, how important would ... be for that job?", where the ellipses are a list of options covering 17 different (potentially) relevant domains, of which we use the six most directly linked to our indicators. Questions are answered on a Likert scale going from 1 ("not at all important") to 5 ("absolutely essential"). 
weights based on the proportion of people who indicated that a given indicator was "somewhat important" (4 on the Likert scale) or "absolutely essential" (5 on the Likert scale). In a second step, we normalise the sum of the proportion to 1 by dividing the proportion who regard each individual domain as "somewhat important" or "absolutely essential" by the sum of the proportion for all six domains. Thus, the relatively greater the number of individuals who think a domain is important, the heavier the weighting it is given. Index 3 works on a similar principle but is slightly more nuanced by accounting for the full distribution of responses. Here, we first sum the responses of each individual on the importance of each domain, then perform the same normalisation as before. This imposes that in Indices 2 and 3, each domain has the same weight for all individuals in society.

Noting that Indices 1-3 impose preference dominance ${ }^{6}$ we develop a fourth that makes use of the variation in individual perceptions about which features are important for a good job to generate a "subjectively weighted index". This approach allows two individuals with the same observable job attributes to have a different level of job quality due to the configuration of his or her perceptions on what constitutes a good job. Normalising these heterogeneous weights, is more complicated as it is not logically consistent for every individual's weights to sum to $1 .{ }^{7}$ We therefore define a hypothetical maximum of 1 that all weights could add up to, with each domain having a potential weight of 0.167 . As perceptions are garnered on a Likert scale of 1-5, each marginal decrease in the reported importance of a domain corresponds with a reduction in this potential weight of $0.033 .{ }^{8}$ We calculate this index as follows:

$$
w_{i j}=\frac{1}{N}\left[\operatorname{Imp}_{i j} \cdot \frac{1}{M}\right]
$$

where the subscript $\mathrm{i}$ denotes a given individual and the subscript $\mathrm{j}$ the domain of interest. Imp is the importance ranking attached to domain $\mathrm{j}$ by individual $\mathrm{i}$. $\mathrm{N}$ denotes the number of domains; and $\mathrm{M}$ the extent of the Likert scale from which individual i can choose the importance of domain $\mathrm{j}$.

Although overcoming preference dominance, such an index is not uncontroversial. Cognitive dissonance literature, for example, suggests that individuals who are dissatisfied with some aspect of their job are less likely to report those aspects as important. In such a case, those with higher degrees of cognitive dissonance may appear to have higher quality jobs without the actually quality of their job being, in any way, higher. In particular, individuals might rank a particular domain as unimportant in order to psychologically protect themselves from an adverse feature of their job. ${ }^{9}$ Our four indices are designed to straddle these

\footnotetext{
${ }^{6}$ Preference dominance occurs when weights are equal for all individuals in a society, thus implying that the preferences of some (hypothetical) individual whose real preferences match these weights dominates the preferences of everyone in society who does not share those preferences.

7 Ceteris paribus, this implies that someone who thinks all six domains are "not at all important" would have the same job quality as someone who thinks all six domains are "absolutely essential".

8 Another approach used in the literature is to regress each domain of interest on self-reported job satisfaction and to generate weights based on the relative explanatory power of each (Kalleberg et al. 2000). Although we generate this index, none of our domains of interest are shown to be a significant determinant of job satisfaction. Therefore, although the results from this analysis do not deviate from those presented in this article, concerns arise about the usefulness and accuracy of the approach in this context. As such, we do not present this approach in this text. Results are available from the authors upon request.

9 In addition, this could also affect how individuals answer questions in the survey, with particular differentiations across "objective" and "subjective" indicators. To consider this concern, we run a robustness check that splits the index into objective indicators (income, hours worked, formality and security) and subjective ones (interestingness and autonomy). Results in both analyses match those from the full index, suggest-
} 
differing concerns and to ensure that findings are robust to the strengths and weaknesses of each. Beginning with Index 1, therefore, we create a weighting regime that does not vary across the population and that is not at all linked to individuals' subjective perceptions; in Indices 2 and 3, we create an index that does not vary across the population but is grounded in perceptions that have been averaged across the entire sample. Finally, in Index 4 , we create a weighting regime that varies across individuals but that is built, entirely, from subjective perceptions. ${ }^{10}$

We normalise each of our six indicators onto the interval $i \in[-1,1]$, as they are otherwise incomparable in scale and units. We choose the interval $i \in[-1,1]$ as it is the only style of interval that remains logically consistent with the weighting mechanism of Index 4. Index 4 requires that an individual who believes that income is an essential component of a good job but who has an incredibly low income is worse off than an individual with the same income but who does not think income is important at all. At the other end of this scale, an individual with a very high income and who thinks income is essential should be better off than one with a high income who thinks it is unimportant. Although the latter of these restrictions holds in other identification methods, such as on an interval $i \in[0,1]$, it does not for the bottom end. We discuss how we implement this normalisation for each domain below.

\subsection{Income}

Our distribution of income runs from 0 to 80,000 Soms/month, with a mean of 8669 Soms/ month. While we can safely assume, ceteris paribus, that higher income should be 'better', it is unclear whether or not an individual with an income twice the mean is doubly better off as one with a mean income. Indeed, basic economic theory might suggest that additional income would suffer diminishing marginal returns. To avoid strong statements on marginal effects, we take deciles of income from the distribution and map them, at even spaces, onto the interval with the top income decile having a value of 1 and the lowest a value of -1 .

\subsection{Hours Worked}

Underemployment is likely to be just as indicative of a "bad job" as overemployment in developing contexts (Behrman 1999; Blattman et al. 2014; World Bank 2012). Thus, in our main indicator we look at the deviation of hours worked from some optimal, which we take to be the monthly mean of hours worked across the sample. ${ }^{11}$ Thus, an individual who works the monthly mean number of hours takes an outcome of 1 . All individuals who work

\footnotetext{
Footnote 9 (continued)

ing our results are not driven only by either subjective or objective indicators. In turn, this implies that cognitive dissonance plays no major role in our analysis. Results of this robustness check are presented in Table 22 .

10 As an additional robustness check, we construct a fifth index that is generated using weightings derived from a factor analysis. These weights are generated using Stata's "predict" command and normalised onto the same scale as the weights of the other indices, such that they sum to one. This index (denoted Index 5) exhibits the same positive and significant relationship with life satisfaction as the indices described here. Results from this analysis are shown in Table 20. We use Stata's default factor analysis settings.

11 To account for potential seasonality, particularly for agricultural workers, we use the mean from the month in which the data was collected, rather than across the whole sample, as a base.
} 
two standard deviations more or less than this mean take a value of -1 . The remainder are distributed across the interval, based on their exact hours worked. ${ }^{12}$

\subsection{Job Security}

Similar to our income domain, we assume that a longer tenure is associated with higher job quality but wish to avoid making strong statements at the margin. Accordingly, we split the duration of employment into deciles, with each decile spaced evenly across the interval.

\subsection{Job Formality}

Both questions that constitute our indicator of job formality are binary variables, taking the value of 1 if a person's position is formal and 0 if not. We simply transpose these outcomes onto the extremes of the interval, taking a value of -1 if a job is informal and 1 if it is formal.

\subsection{Interestingness of a Job}

Interestingness of a job is reported directly on a Likert scale going from 1 ("uninteresting") to 3 ("very interesting"), which we space at equal intervals across the interval. ${ }^{13}$

\subsection{Job Autonomy}

Autonomy is, again, asked directly but is reported on a Likert scale running from 1 ("no autonomy") to 4 ("high autonomy"). These responses are spaced at even intervals across the interval.

In a final stage, to ensure manageability of the coefficients, each index is then mapped onto the interval $J Q_{j} \in[0,100]$. We repeat each step using corresponding weighting mechanisms for indices comprised only of hours worked and income.

Summary statistics and group comparisons for each of the full indices are shown in Table 2. Across all indices, wageworkers have significantly better jobs than the selfemployed but in general, job quality is in the medium range. We show the distribution of Indices 1 and 4 in Fig. 1. ${ }^{14}$

\footnotetext{
${ }^{12}$ We note that this may contrast with the basic model of labour supply, in that all hours worked should interact negatively with welfare. Therefore, as a robustness check, we transform hours worked into deciles, which we then transform onto an interval $i \in[-1,1]$, such that those who work the greatest number of hours receive a transformed indicator of -1 , those who work the least (or not at all) receiving a transformed indicator of 1 , with the other deciles equally spaced at intervals in between. Results using the indices created in this way are shown in Tables 18 and 19 and show no material differences in terms of the sign, scale or significance of the coefficients presented in the main analyses.

13 This implies that an individual reporting "somewhat interesting" ( 2 on the Likert scale) has a normalised value of 0 , meaning that a person who thinks interestingness is essential and has a somewhat interesting job will have the same weighted value as one who has a somewhat interesting job but who thinks interestingness is unimportant. We argue that, since it is unclear here who should be better off in this scenario that this, although potentially undesirable, is not problematic. This still allows all people with "very interesting" jobs to be better off than those with "somewhat interesting" jobs, who in turn are better off than those with "uninteresting" jobs.

${ }^{14}$ Noting that some of these indicators may inherently be "worse" for young people (e.g. it is almost guaranteed that an 18 year old will have low job security by our measure, as he or she has a much lower "maximum" tenure than older indivduals), we generate an age-weighted version of each index. These indices mul-
} 
Table 2 Summary statistics of job quality indices
Variables (1) (2) (3)

(4)

Employed Selfemployed Wageworkers Difference

\begin{tabular}{lllll}
\hline Index 1 & 55.54 & 52.41 & 57.88 & $-5.47 * * *$ \\
Index 2 & 56.54 & 53.67 & 58.67 & $-5.01 * * *$ \\
Index 3 & 56.24 & 53.09 & 58.58 & $-5.49 * * *$ \\
Index 4 & 48.28 & 45.82 & 50.12 & $-4.30^{* * *}$ \\
Observations & 2585 & 1044 & 1425 & \\
\hline
\end{tabular}

$* * * p<0.01 ; * * p<0.05 ; * p<0.1$
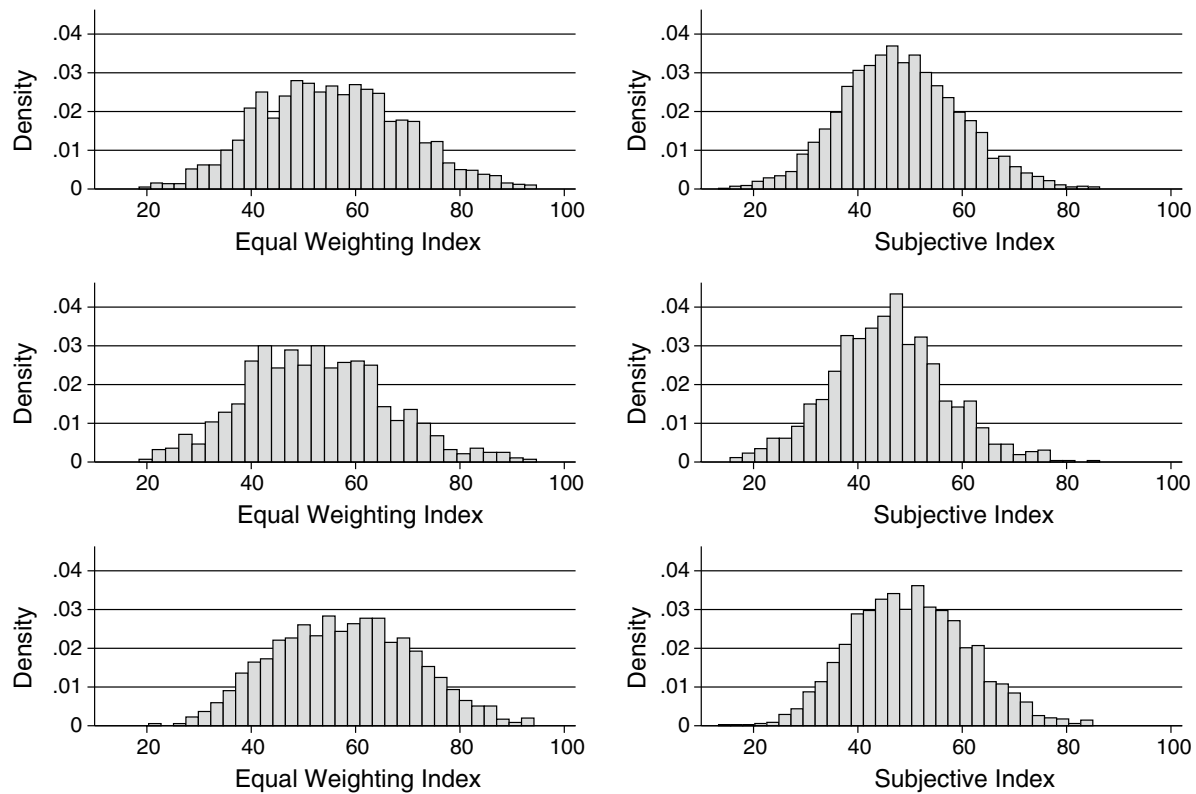

Fig. 1 Histograms showing the distribution of Index 1 (left hand side) and Index 4 (right hand side) for all workers (top row), the self-employed (middle row) and wageworkers (bottom row)

We note a number of potential and interesting trade-offs that can arise from this approach. For example, while an increase in income acts to improve job quality, this may come at the cost of increasing the number of hours one works. The number of hours worked, at least beyond a certain point, acts to deflate an individual's job quality, however. In turn, the net impact on job quality might not be immediately obvious. Similarly, a move from a formal job to a similar informal job may result in increases in income or improvements in the other domains, but reductions in other domains as per Chen (2007). In turn, the net effect on job quality is, again, ambiguous as declines in one domain (formality) are

Footnote 14 (continued)

tiply the final index by the inverse of age. Thus, ceteris paribus, the younger of two people with the same preferences and job features are better off in this index. We show results from these analysis in Tables 1417 
Table 3 Factor analysis showing uniqueness of each domain

\begin{tabular}{llcl}
\hline Variables & $(1)$ & $(2)$ & $(3)$ \\
& Factor 1 & Factor 2 & Uniqueness \\
\hline Income & 0.4116 & 0.4204 & 0.6538 \\
Hours & 0.3689 & 0.1380 & 0.8449 \\
Formality & 0.7070 & -0.3471 & 0.3796 \\
Interesting & 0.7631 & 0.0863 & 0.4102 \\
Autonomy & 0.1660 & 0.5552 & 0.6642 \\
Security & 0.2092 & -0.6528 & 0.5302 \\
Observations & 2585 & 2585 & 2585 \\
\hline
\end{tabular}

Table 4 Unconditional correlations of each domain

\begin{tabular}{lllclcr}
\hline & Income & Hours & Formality & Interesting & Autonomy & Security \\
\hline Income & 1.000 & & & & & \\
Hours & 0.0621 & 1.000 & & & & \\
Formality & 0.0610 & 0.0697 & 1.000 & & & \\
Interesting & 0.1478 & 0.1205 & 0.3271 & 1.000 & & \\
Autonomy & 0.0522 & 0.0035 & -0.0076 & 0.0773 & 1.000 & \\
Security & 0.0072 & 0.0095 & 0.1216 & 0.0048 & -0.0008 & 1.000 \\
\hline
\end{tabular}

counteracted with increases in others. In turn, although we suggest that, ceteris paribus, formal jobs should be preferred to informal ones, the outcome in the real world is not so clear as it is unlikely that only the formality of work changes during such a switch. Given the interaction of (in)formality with the other domains it does not immediately follow that a move to an informal job results in a decrease in job quality. This mutual reliance amongst the domains and the kinds of trade-offs implied are suggestive of the essential essence and richness of the multiple domain index approach.

Informal employment in Kyrgyzstan is defined as an employment without state registration which is largely in line with our criteria of defining informality. Jobs in informal settings constitute about two-thirds of total employment in the country (NSC 2017). Most informal workers are short-term wage employees (39\% of all informally employed), farmers $(26 \%)$ and self-employed (25\%). Across sectors, informal jobs are concentrated in agriculture (39\% of total informal employment), trade (20\%), and construction (15\%). Due to the land and small-and medium enterprise privatization in mid-1990s, informal activities tend to be organised horizontally as there are few large and vertically organised private enterprises.

We conduct a factor analysis on the sub-domains in order to test the uniqueness of each, and thus, to consider their contribution to our indices. As can be seen in Table 3, most indicators exhibit a middle to high level of uniqueness, suggesting that they explain something that the other domains, either alone or in combination, do not. By a similar token, as shown in Table 4, the unconditional correlation between each domain is generally in a relatively low range. We therefore conclude that the outcomes presented in this article are driven by the combination of all six domains and the trade-offs inherent therein, rather than individual components of the indices. 
Fig. 2 Histogram showing the distribution of subjective wellbeing

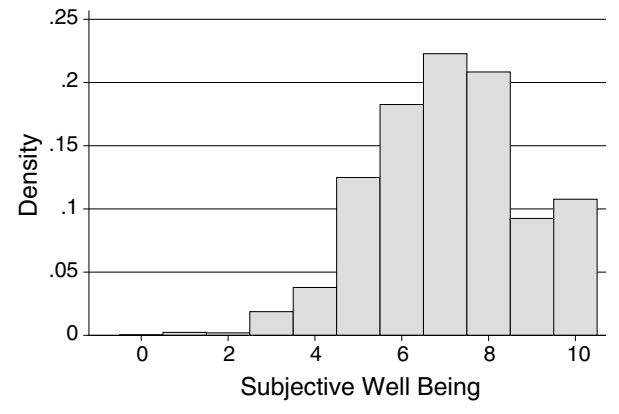

We match each index to self-reported wellbeing, derived from a question that asks, "How satisfied are you with your life, all things considered?" Responses are given on a 11-point Likert scale running from 0 ("completely dissatisfied") to 10 ("completed satisfied"). We show the distribution of this variable in Fig. 2. A previous study shows the suitability of the LiK data for the research of subjective wellbeing (Bertram-Hümmer and Baliki 2015). We control for robust determinants of subjective wellbeing (see Dolan et al. 2008, for a review), including: age, gender and ethnicity; educational background; participation in religious, social or community groups; health; regional controls; and personality and attitudes to risk and other circumstances. We define all included controls in Table 9.

The use of self-reported wellbeing is not uncontroversial (Andrews and McKennell 1980; Pavot and Diener 1993) as a number of features of an individual's psyche may influence the response. Should these traits also correlate with those that affect labour market performance (Borghans et al. 2008; Brunello and Schlotter 2011; Groves 2005; Heckman et al. 2006) biases may arise in OLS models. To overcome this, we include two sets of personality controls. The first are "attitudinal" indicators, comprising risk profiles and response to circumstances. The second uses data reduction techniques on a 21-question personality test. ${ }^{15}$ In combination, these variables overcome typical sources of bias, particularly because subjective wellbeing should not influence job quality directly. In turn, this suggests that OLS and probit modelling are sufficient. We thus estimate:

$$
S W B_{j}=\alpha+\beta_{i} J Q_{i j}+\gamma X_{j}+\rho P E R S_{j}+\delta \text { Region }_{k}+u_{j}
$$

where $S W B_{j}$ is subjective wellbeing for individual $j ; J Q_{i j}$ is job quality for individual $j$ measured by index $i ; X_{j}$ is an $(h \times 1)$ vector of $h$. control variables; $P E R S_{j}$ is an $(l \times 1)$ vector of $l$ personality controls; Region $n_{k}$ is a regional fixed effect for location $k ; u_{j}$ is an idiosyncratic error term; and $\beta_{i}, \gamma, \rho$ and $\delta_{k}$ are vectors of regression coefficients.

As $S W B_{j}$ is implicitly ordinal, we repeat the analysis using ordered probits. We thus implement:

$$
S W B_{j}^{*}=\beta_{i} \text { JobQuality }_{i j}+\gamma_{h} X_{h j}+\rho_{h} \text { personality }_{h j}+\delta_{k} \text { oblast }_{k}+u_{j}
$$

where $S W B_{j}^{*}$ is a latent variable measuring individual $j$ 's self-reported welfare; and the other components of Eq. (4) are as previously described. For any given individual, it is likely that a high level of job quality will translate into a high level of welfare and that low

\footnotetext{
15 To generate these variables, we conduct a factor analysis on the full set of 21 questions, and focus on the factors that explain most of the variation. In this particular case, we include each factor that explains more than $10 \%$ of the variation. In the second step, we include in the regressions the question that is most highly correlated with each of these factors.
} 
Table 5 OLS analysis of income and hours worked sub-indices on self-reported wellbeing

\begin{tabular}{lllll}
\hline Variables & $(1)$ & $(2)$ & $(3)$ & $(4)$ \\
& Wage-hours1 & Wage-hours2 & Wage-hours3 & Wage-hours4 \\
\hline Wage-hours1 & 0.00191 & & & \\
& $(0.00146)$ & & & \\
Wage-hours2 & & 0.00177 & & \\
& & $(0.00142)$ & & \\
Wage-hours3 & & & 0.00177 & \\
& & & $(0.00147)$ & 0.00164 \\
Wage-hours4 & & & \\
& Yes & Yes & Yes & Yes \\
Demographic & Yes & Yes & Yes & Yes \\
Regional & Yes & Yes & Yes & Yes \\
Health & Yes & Yes & Yes & Yes \\
Participation & Yes & Yes & Yes & Yes \\
Personality & Yes & Yes & Yes & Yes \\
Attitudes & 2460 & 2460 & 2460 & 2460 \\
Observations & 0.356 & 0.356 & 0.456 & 0.356 \\
R-squared & & & & \\
\hline
\end{tabular}

Standard errors in parentheses. $* * * p<0.01 ; * * p<0.05 ; * p<0.1$. Demographic, regional, health, participation, personality and attitudes refer to broad groupings of control variables

job quality will translate into low welfare. Therefore, the observed and coded discrete subjective wellbeing, $S W B_{j}^{*}$ is determined from the model as follows:

$$
S W B_{j}=\left\{\begin{array}{c}
0 \text { if }-\infty \leq S W B_{j}^{*} \leq \mu_{1} \text { (“completely dissatisfied") } \\
\vdots \\
m \text { if } \mu_{n+1} \leq S W B_{j}^{*} \leq \mu_{m} \\
\vdots \\
\text { if } \mu_{10} \leq S W B_{j}^{*} \leq \infty \text { ("completely satisfied") }
\end{array}\right.
$$

\section{Results}

We present results in Tables 5, 6, 7 and 8. In Tables 5 and 6, we display the outcomes from the OLS analyses on Indices $1-4$. Tables 7 and 8 show the results from ordered probit analyses. Results from the truncated indices composed of hours worked and income are shown in Tables 5 and 7, with those from the full indices in Tables 6 and 8. Each table comprises four columns, with each corresponding, respectively, to the four weighting mechanisms discussed in Sect. 2.

As can be seen in Tables 5 and 7, these analyses show no statistically significant relationship between the truncated job quality indices, composed only of hours worked and income, and life satisfaction. By contrast the full indices in Tables 6 and 8 show a significant and robust relationship with all four versions of the index. As can be seen in Table 20, these results are also robust to the use of a fifth index, based on weights generated from a factor analysis on the included domains. Thus, while we present evidence that higher 
Table 6 OLS analysis of full job quality indices on self-reported wellbeing

\begin{tabular}{lllll}
\hline Variables & $(1)$ & $(2)$ & $(3)$ & $(4)$ \\
& index1 & Index2 & index3 & index4 \\
\hline index1 & $\begin{array}{l}0.00768^{* * *} \\
(0.00246)\end{array}$ & & & \\
& & $0.00744^{* * *}$ & & \\
index2 & & $(0.00252)$ & & \\
& & & $0.00683 * * *$ & \\
index3 & & & $(0.00256)$ & \\
& & & $0.00760^{* * *}$ \\
index4 & & & & $(0.00294)$ \\
& & & Yes & Yes \\
Demographic & Yes & Yes & Yes & Yes \\
Regional & Yes & Yes & Yes & Yes \\
Health & Yes & Yes & Yes & Yes \\
Participation & Yes & Yes & Yes & Yes \\
Personality & Yes & Yes & Yes & Yes \\
Attitudes & Yes & Yes & 2460 & 2460 \\
Observations & 2460 & 2460 & 0.358 & 0.358 \\
R-squared & 0.358 & 0.358 & & \\
\hline
\end{tabular}

Standard errors in parentheses. $* * * p<0.01 ; * * p<0.05 ; * p<0.1$. Demographic, regional, health, participation, personality and attitudes refer to broad groupings of control variables

Table 7 Ordered probit analysis of income and hours worked sub-indices on self-reported wellbeing

\begin{tabular}{lllll}
\hline Variables & $(1)$ & $(2)$ & $(3)$ & $(4)$ \\
& Wage-hours1 & Wage-hours2 & Wage-hours3 & Wage-hours4 \\
\hline Wage-hours1 & 0.00142 & & & \\
& $(0.00108)$ & & & \\
Wage-hours1 & & 0.00132 & & \\
& & $(0.00105)$ & & \\
Wage-hours3 & & & 0.00133 & \\
& & & $(0.00108)$ & 0.00125 \\
Wage-hours4 & & & & $(0.00120)$ \\
& & Yes & Yes & Yes \\
Demographic & Yes & Yes & Yes & Yes \\
Regional & Yes & Yes & Yes & Yes \\
Health & Yes & Yes & Yes & Yes \\
Participation & Yes & Yes & Yes & Yes \\
Personality & Yes & Yes & Yes & 2460 \\
Attitudes & Yes & 2460 & 2460 & \\
Observations & 2460 & & & \\
\hline
\end{tabular}

Standard errors in parentheses. $* * * p<0.01$; ** $p<0.05$; $* p<0.1$. Demographic, regional, health, participation, personality and attitudes refer to broad groupings of control variables 
Table 8 Ordered probit analysis of full job quality indices on selfreported wellbeing

\begin{tabular}{|c|c|c|c|c|}
\hline Variables & $\begin{array}{l}\text { (1) } \\
\text { Index1 }\end{array}$ & $\begin{array}{l}\text { (2) } \\
\text { Index2 }\end{array}$ & $\begin{array}{l}\text { (3) } \\
\text { Index3 }\end{array}$ & $\begin{array}{l}\text { (4) } \\
\text { Index4 }\end{array}$ \\
\hline Index 1 & $\begin{array}{l}0.00584 * * * \\
(0.00182)\end{array}$ & & & \\
\hline Index 2 & & $\begin{array}{l}0.00565 * * * \\
(0.00187)\end{array}$ & & \\
\hline Index3 & & & $\begin{array}{l}0.00521 * * * \\
(0.00190)\end{array}$ & \\
\hline Index 4 & & & & $\begin{array}{l}0.00575^{* * *} * \\
(0.00218)\end{array}$ \\
\hline Demographic & Yes & Yes & Yes & Yes \\
\hline Regional & Yes & Yes & Yes & Yes \\
\hline Health & Yes & Yes & Yes & Yes \\
\hline Participation & Yes & Yes & Yes & Yes \\
\hline Personality & Yes & Yes & Yes & Yes \\
\hline Attitudes & Yes & Yes & Yes & Yes \\
\hline Observations & 2460 & 2460 & 2460 & 2460 \\
\hline
\end{tabular}

Standard errors in parentheses. $* * * p<0.01, * * p<0.05, * p<0.1$. Demographic, regional, health, participation, personality and attitudes refer to broad groupings of control variables

job quality results in increased subjective well-being in Kyrgyzstan, we note that truncated measures based on hours worked and income are insufficient to capture or explain this relationship. At the headline level these results show the relevance of job quality concept to developing world and transition contexts, whilst also implying the need for more sophisticated measures of job quality in these contexts. In the first instance, this confirms the need for "decent jobs" as well as employment more generally in developing countries; and second, there is need to consider job quality more broadly than just income and the time spent working, as per the classic model of labour supply, and in line with the job-demandscontrol model.

More specifically Table 6 shows that an increase in job quality of 1 point on a 100-point scale is associated with an improvement in subjective wellbeing of between 0.0068 and 0.0077 points. Although this effect is, superficially, economically small, it implies that at the mean, a 10-point increase in job quality leads to an increase in self-reported wellbeing of between 0.07 and 0.08 points. In Index 3, where the coefficient is smallest, this implies that subjective wellbeing increases from 7.06 at the mean to 7.14; in Index 1, where the coefficient is largest, subjective wellbeing increases to 7.15. As shown in Fig. 2, the distribution of subjective well-being is strongly clustered at five or higher. In proportional terms, therefore, such a change is not an insignificant improvement. While the effect is not very pronounced, a large number of individual, household, community, country and regional factors are also captured by a measure as wide as subjective life satisfaction. In turn, we posit that nuanced measures of job quality remain important and significant drivers of wellbeing.

Full results from these analyses can be seen in Tables 10, 11, 12 and 13 and robustness checks using slight variations in the construction of the indices or weighting regimes in Tables 18, 19 and 20. In all regressions, we find robustly that age is negatively correlated with subjective wellbeing, meaning that, in Kyrgyzstan, younger people tend to be more 
satisfied than older people. That age squared is positive, however, implies that although life satisfaction declines in age, it does so at a decelerating rate. Those with higher education are typically those with higher wellbeing, whilst wageworkers display lower wellbeing than the self-employed. We find that personality features are correlated with wellbeing, with self-reported ingenuity and strong and positive driver of life satisfaction. Those with low risk aversion exhibit higher wellbeing as do those who report that they adapt well to changing circumstances. Finally, we find evidence that wellbeing is linked to the oblast (region) in which an individual is resident.

\section{Conclusion}

In this article, we explore job quality - measured both broadly, in the spirit of Clark (2005), and narrowly in terms of hours worked and income, as per the classical model of labour market supply. We analyse the relationship between job quality and (subjective) wellbeing in the developing and transition context of Kyrgyzstan. Despite a long line of literature focussing on how to measure job quality, analyses of the relationship between wider measures of job quality and welfare has been dominated by work focussing on advanced economies (see Gallie 2009; Green 2007). Consequently, general questions remain. These include whether or not the concept of job quality is equally valid in developing contexts as developed ones, and about the extent to which wider measures are more satisfactory in those contexts than narrower ones. In this article, we overcome these issues by setting our analysis in Kyrgyzstan, a post-Soviet lower middle-income country and by developing two competing conceptualisations of job quality: a broad index built around six domains (income, hours worked, autonomy, interestingness, security and formality) and a narrow one, built only from income and hours worked.

We show that the indices comprising only hours worked and income are insufficient to derive a relationship between job quality and welfare but that the broader indices exhibit a positive and significant relationship, showing that life satisfaction increases as job quality improves. These results are robust across a range of weighting regimes and two empirical specifications. In addition, they are also robust to the inclusion or exclusion of groups of control variables and to alternative indices that allow job quality to vary by age.

In general, these results are grounded in a wider literature from the developed world that supports this general relationship. More so, the findings fit with the job-demands-control theory of the relationship between work and welfare, whilst contradicting the effortreward-imbalance model. The latter model suggests that the link between welfare and work is a function of the balance between the demands of the job and the corresponding rewards. In other words, the major drivers of job quality are analogous to those in the basic model of labour-supply. By contrast, the job-demands-control model focuses on "higher-order" concepts, such as workers' level of control. Our results support the notion that these higherorder aspects of work, such as the interestingness of the job, the complexity of the tasks, and the autonomy one has to complete them are important factors in how work links to welfare. Effort and reward (viewed in terms of hours worked and income) are insufficient to explain the relationship between work and welfare.

At the same time wider literature has previously suggested that narrower measures of job quality should also be sufficient to capture the relationship with subjective wellbeing. McBride (2001), Diener and Oishi (2000), Cummins (2000), Ferrer-i-Carbonnel (2005) and Diener and Biswas-Diener (2002) all show a positive relationship between income and 
wellbeing, whilst Wooden et al. (2009), Meier and Stutzer (2008), and Schoon et al. (2005) show the same relationship with hours worked. We show that hours worked and income, alone, are insufficient to determine this relationship in Kyrgyzstan. This may imply that general working conditions are more important in Kyrgyzstan than anticipated in this previous body of work. In many ways, perhaps this is understandable. More than a third of our sample work informally, implying certain layers of exclusion from wider society that are significantly less relevant in the developed world, where significantly fewer people work informally. Similarly, more than half of our sample have jobs that, by duration of tenure, we do not consider "secure", whilst over $45 \%$ are self-employed, which is a significantly larger proportion than one expects in the developed world. In combination, these features of the Kyrgyz labour market may act to underpin the results presented here and to reinforce the requirement to more deeply understand job quality in developing and transition economies.

These results, therefore, provide important information on measuring job quality in labour markets in general and for those in the developing world, in particular. On the one hand, that a strong and significant relationship endures between job quality and wellbeing in Kyrgyzstan suggests that the job quality concept is just as important in developing contexts as they are in advanced economies, adding credence to interventions focussed on "decent jobs". As such outcomes are dependent on the mechanism used to define job quality, however, the role of poor conceptualisation or measurement of job quality should not be underestimated in these scenarios. It is, thus, important to consider job quality in developing contexts as much in terms of security, formality, interestingness and the autonomy they afford as it is to focus on work in terms of only income or the time devoted to generating this income.

Acknowledgements We are grateful to participants of the LEADS Conference in Berlin 2016, IZA conferences in Rome and London 2016, the Life in Kyrgyzstan Conference in Bishkek in 2015, First World Congress of Comparative Economics in Rome 2015 and to the attendees at economics seminars at RuhrUniversität Bochum in 2014 and Universität Potsdam in 2015 for valuable comments. We additionally thank Anastaisa Aladysheva, Kathryn Anderson, Armando Barrientos, Charles Becker, Tilman Brück, Hartmut Lehmann and Susan Steiner for additional reviews, critiques and suggestions. All remaining errors are our own.

Funding This document is an output from a project funded by the UK Department for International Development (DFID) and the Institute for the Study of Labor (IZA) for the benefit of developing countries. The views expressed are not necessarily those of DFID or IZA.

\section{Compliance with Ethical Standards}

Conflict of interest The authors declare that they have no conflict of interest.

Open Access This article is distributed under the terms of the Creative Commons Attribution 4.0 International License (http://creativecommons.org/licenses/by/4.0/), which permits unrestricted use, distribution, and reproduction in any medium, provided you give appropriate credit to the original author(s) and the source, provide a link to the Creative Commons license, and indicate if changes were made.

\section{Appendix}

See Tables 9, 10, 11, 12, 13, 14, 15, 16, 17, 18, 19, 20, 21 and 22. 


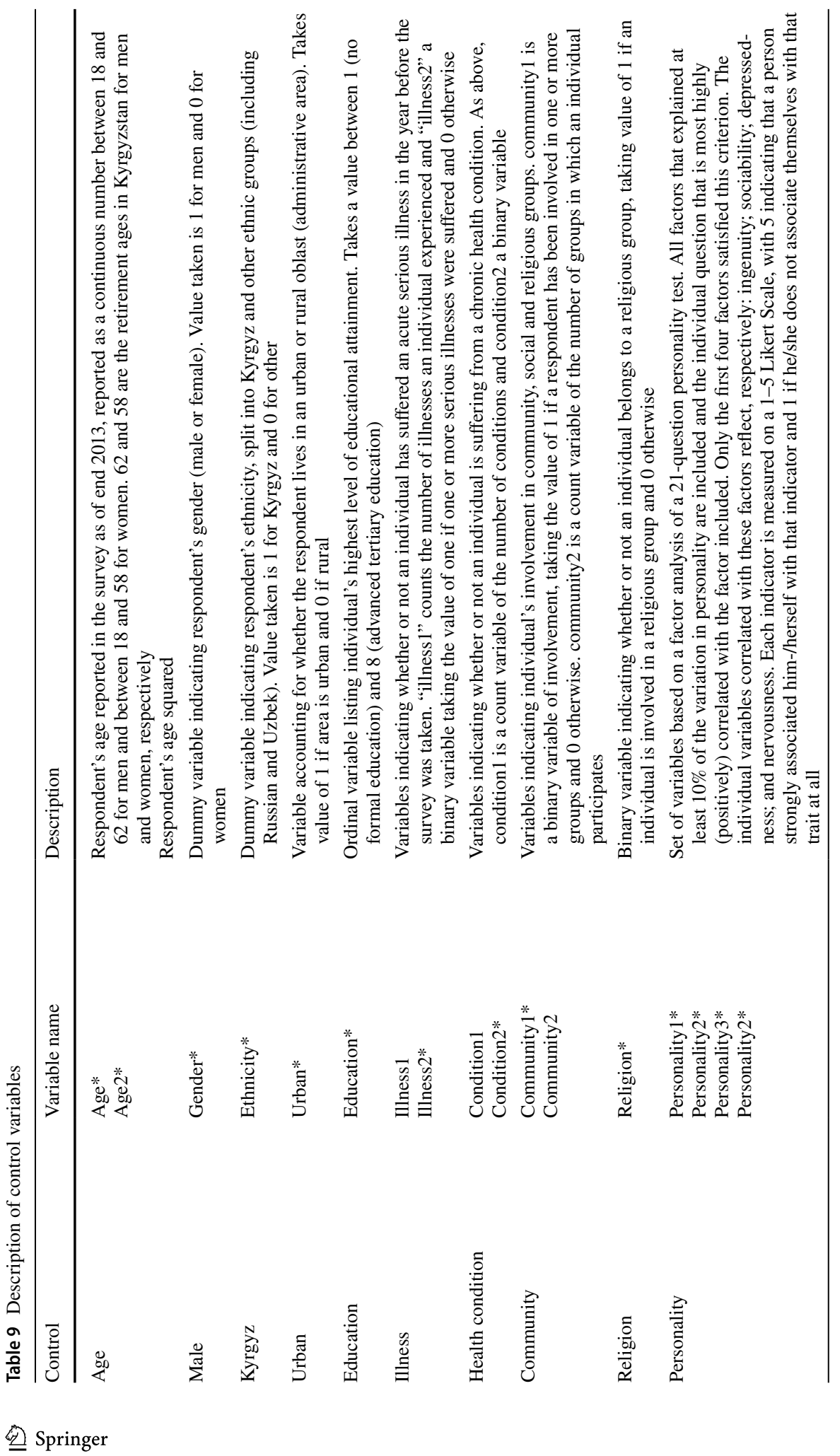




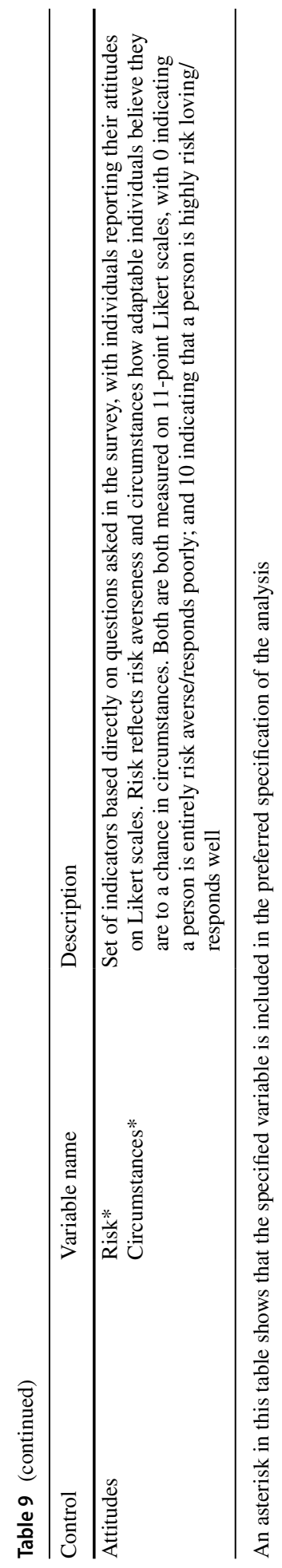


Table 10 Full results from OLS analysis of hours worked and wage sub-indices

\begin{tabular}{|c|c|c|c|c|}
\hline \multirow[t]{2}{*}{ Variables } & (1) & (2) & (3) & (4) \\
\hline & Wage-hours1 & Wage-hours2 & Wage-hours3 & Wage-hours 4 \\
\hline \multirow[t]{2}{*}{ Wage-hours } & 0.00191 & 0.00177 & 0.00177 & 0.00164 \\
\hline & $(0.00146)$ & $(0.00142)$ & $(0.00147)$ & $(0.00163)$ \\
\hline \multirow[t]{2}{*}{ Age } & $-0.0414 * *$ & $-0.0414 * *$ & $-0.0414^{* *}$ & $-0.0413 * *$ \\
\hline & $(0.0189)$ & $(0.0189)$ & $(0.0189)$ & $(0.0189)$ \\
\hline \multirow[t]{2}{*}{ Age2 } & $0.0440 *$ & $0.0441^{*}$ & $0.0441 *$ & $0.0439 *$ \\
\hline & $(0.0239)$ & $(0.0239)$ & $(0.0239)$ & $(0.0239)$ \\
\hline \multirow[t]{2}{*}{ Gender } & -0.0491 & -0.0488 & -0.0486 & -0.0459 \\
\hline & $(0.0645)$ & $(0.0645)$ & $(0.0646)$ & $(0.0645)$ \\
\hline \multirow[t]{2}{*}{ Ethnicity } & 0.0559 & 0.0557 & 0.0555 & 0.0550 \\
\hline & $(0.0692)$ & $(0.0692)$ & $(0.0692)$ & $(0.0692)$ \\
\hline \multirow[t]{2}{*}{ Urban } & -0.0759 & -0.0758 & -0.0757 & -0.0736 \\
\hline & $(0.0887)$ & $(0.0887)$ & $(0.0888)$ & $(0.0887)$ \\
\hline \multirow[t]{2}{*}{ Education } & $0.0525 * *$ & $0.0527 * *$ & $0.0528 * *$ & $0.0533^{* *}$ \\
\hline & $(0.0237)$ & $(0.0237)$ & $(0.0237)$ & $(0.0238)$ \\
\hline \multirow[t]{2}{*}{ Employer } & 0.0148 & 0.0155 & 0.0159 & 0.0216 \\
\hline & $(0.296)$ & $(0.296)$ & $(0.296)$ & $(0.296)$ \\
\hline \multirow[t]{2}{*}{ Wageworker } & $-0.157 * *$ & $-0.156^{* *}$ & $-0.156^{* *}$ & $-0.157 * *$ \\
\hline & $(0.0700)$ & $(0.0700)$ & $(0.0700)$ & $(0.0700)$ \\
\hline \multirow[t]{2}{*}{ Family } & 0.0436 & 0.0429 & 0.0425 & 0.0378 \\
\hline & $(0.118)$ & $(0.118)$ & $(0.118)$ & $(0.118)$ \\
\hline \multirow[t]{2}{*}{ Illness2 } & -0.0240 & -0.0239 & -0.0238 & -0.0234 \\
\hline & $(0.0648)$ & $(0.0648)$ & $(0.0648)$ & $(0.0648)$ \\
\hline \multirow[t]{2}{*}{ Condition 2} & -0.121 & -0.121 & -0.121 & -0.122 \\
\hline & $(0.0802)$ & $(0.0802)$ & $(0.0802)$ & $(0.0802)$ \\
\hline \multirow[t]{2}{*}{ Community 1} & 0.0594 & 0.0596 & 0.0598 & 0.0598 \\
\hline & $(0.0575)$ & $(0.0575)$ & $(0.0575)$ & $(0.0575)$ \\
\hline \multirow[t]{2}{*}{ Religion } & -0.262 & -0.263 & -0.263 & -0.265 \\
\hline & $(0.256)$ & $(0.256)$ & $(0.256)$ & $(0.256)$ \\
\hline \multirow[t]{2}{*}{ Personality 1} & $0.0994 * * *$ & $0.0995 * * *$ & $0.0996 * * *$ & $0.100 * * *$ \\
\hline & $(0.0312)$ & $(0.0312)$ & $(0.0312)$ & $(0.0312)$ \\
\hline \multirow[t]{2}{*}{ Personality2 } & $-0.0370^{*}$ & $-0.0370^{*}$ & $-0.0370^{*}$ & $-0.0369^{*}$ \\
\hline & $(0.0220)$ & $(0.0220)$ & $(0.0220)$ & $(0.0220)$ \\
\hline \multirow[t]{2}{*}{ Personality 3} & $-0.0472^{*}$ & $-0.0471^{*}$ & $-0.0470^{*}$ & -0.0468 \\
\hline & $(0.0285)$ & $(0.0285)$ & $(0.0285)$ & $(0.0285)$ \\
\hline \multirow[t]{2}{*}{ Personality4 } & 0.0308 & 0.0309 & 0.0310 & 0.0312 \\
\hline & $(0.0286)$ & $(0.0286)$ & $(0.0286)$ & $(0.0286)$ \\
\hline \multirow[t]{2}{*}{ Risk } & $0.0632 * * *$ & $0.0632 * * *$ & $0.0633 * * *$ & $0.0635^{* * *} *$ \\
\hline & $(0.0112)$ & $(0.0112)$ & $(0.0112)$ & $(0.0112)$ \\
\hline \multirow[t]{2}{*}{ Circumstances } & $0.489 * * *$ & $0.489 * * *$ & $0.489 * * *$ & $0.490 * * *$ \\
\hline & $(0.0177)$ & $(0.0177)$ & $(0.0177)$ & $(0.0177)$ \\
\hline \multirow[t]{2}{*}{ Oblast1 } & $0.823 * * *$ & $0.824 * * *$ & $0.824 * * *$ & $0.823 * * *$ \\
\hline & $(0.171)$ & $(0.171)$ & $(0.171)$ & $(0.171)$ \\
\hline Oblast2 & $0.397 * *$ & $0.397 * *$ & $0.397 * *$ & $0.396 * *$ \\
\hline
\end{tabular}


Table 10 (continued)

\begin{tabular}{lllll}
\hline Variables & $(1)$ & $(2)$ & $(3)$ & $(4)$ \\
& Wage-hours1 & Wage-hours2 & Wage-hours3 & Wage-hours4 \\
\hline \multirow{2}{*}{ Oblast3 } & $(0.180)$ & $(0.180)$ & $(0.180)$ & $(0.180)$ \\
& $-0.418^{* *}$ & $-0.417^{* *}$ & $-0.417^{* *}$ & $-0.414^{* *}$ \\
Oblast4 & $(0.200)$ & $(0.200)$ & $(0.200)$ & $(0.200)$ \\
& $1.119^{* * *}$ & $1.120^{* * *}$ & $1.121^{* * *}$ & $1.122^{* * *}$ \\
Oblast5 & $(0.177)$ & $(0.177)$ & $(0.177)$ & $(0.177)$ \\
& $0.299^{*}$ & $0.300^{*}$ & $0.300^{*}$ & $0.302^{*}$ \\
Oblast6 & $(0.180)$ & $(0.180)$ & $(0.180)$ & $(0.180)$ \\
& $0.861^{* * *}$ & $0.863^{* * *}$ & $0.863^{* * *}$ & $0.866^{* * *}$ \\
Oblast7 & $(0.191)$ & $(0.191)$ & $(0.191)$ & $(0.191)$ \\
& $0.709^{* * *}$ & $0.710^{* * *}$ & $0.711^{* * *}$ & $0.714^{* * *}$ \\
Oblast8 & $(0.169)$ & $(0.169)$ & $(0.169)$ & $(0.169)$ \\
& $0.447 * * *$ & $0.449^{* * *}$ & $0.449^{* * *}$ & $0.452^{* * *}$ \\
Constant & $(0.153)$ & $(0.153)$ & $(0.153)$ & $(0.153)$ \\
& $3.540^{* * *}$ & $3.545^{* * *}$ & $3.544^{* * *}$ & $3.538^{* * *}$ \\
Observations & $(0.447)$ & $(0.447)$ & $(0.447)$ & $(0.447)$ \\
R-squared & 2460 & 2460 & 2460 & 2460 \\
\hline
\end{tabular}

Standard errors in parentheses

${ }^{* * *} p<0.01 ; * * p<0.05 ; * p<0.1$ 
Table 11 Full results from OLS analysis of full indices

\begin{tabular}{|c|c|c|c|c|}
\hline Variables & $\begin{array}{l}\text { (1) } \\
\text { Index 1 }\end{array}$ & $\begin{array}{l}\text { (2) } \\
\text { Index } 2\end{array}$ & $\begin{array}{l}\text { (3) } \\
\text { Index3 }\end{array}$ & $\begin{array}{l}\text { (4) } \\
\text { Index4 }\end{array}$ \\
\hline Index & $\begin{array}{l}0.00768 * * * \\
(0.00246)\end{array}$ & $\begin{array}{l}0.00744 * * * \\
(0.00252)\end{array}$ & $\begin{array}{l}0.00683 * * * \\
(0.00256)\end{array}$ & $\begin{array}{l}0.00760 * * * \\
(0.00294)\end{array}$ \\
\hline Age & $\begin{array}{l}-0.0443^{* *} \\
(0.0189)\end{array}$ & $\begin{array}{l}-0.0447^{* *} \\
(0.0189)\end{array}$ & $\begin{array}{l}-0.0431 * * \\
(0.0189)\end{array}$ & $\begin{array}{l}-0.0438^{* *} \\
(0.0189)\end{array}$ \\
\hline Age2 & $\begin{array}{l}0.0460 * \\
(0.0239)\end{array}$ & $\begin{array}{l}0.0464 * \\
(0.0239)\end{array}$ & $\begin{array}{l}0.0449 * \\
(0.0239)\end{array}$ & $\begin{array}{l}0.0456^{*} \\
(0.0239)\end{array}$ \\
\hline Gender & $\begin{array}{l}-0.0424 \\
(0.0635)\end{array}$ & $\begin{array}{l}-0.0457 \\
(0.0636)\end{array}$ & $\begin{array}{l}-0.0435 \\
(0.0636)\end{array}$ & $\begin{array}{l}-0.0432 \\
(0.0636)\end{array}$ \\
\hline Ethnicity & $\begin{array}{l}0.0563 \\
(0.0691)\end{array}$ & $\begin{array}{l}0.0563 \\
(0.0691)\end{array}$ & $\begin{array}{l}0.0557 \\
(0.0691)\end{array}$ & $\begin{array}{l}0.0574 \\
(0.0691)\end{array}$ \\
\hline Urban & $\begin{array}{l}-0.0797 \\
(0.0884)\end{array}$ & $\begin{array}{l}-0.0793 \\
(0.0884)\end{array}$ & $\begin{array}{l}-0.0804 \\
(0.0885)\end{array}$ & $\begin{array}{l}-0.0759 \\
(0.0884)\end{array}$ \\
\hline Education & $\begin{array}{l}0.0348 \\
(0.0245)\end{array}$ & $\begin{array}{l}0.0365 \\
(0.0245)\end{array}$ & $\begin{array}{l}0.0382 \\
(0.0245)\end{array}$ & $\begin{array}{l}0.0391 \\
(0.0245)\end{array}$ \\
\hline Employer & $\begin{array}{l}-0.0252 \\
(0.295)\end{array}$ & $\begin{array}{l}-0.0216 \\
(0.295)\end{array}$ & $\begin{array}{l}-0.0198 \\
(0.296)\end{array}$ & $\begin{array}{l}-0.00986 \\
(0.295)\end{array}$ \\
\hline Wageworker & $\begin{array}{l}-0.166^{* *} \\
(0.0699)\end{array}$ & $\begin{array}{l}-0.163 * * \\
(0.0699)\end{array}$ & $\begin{array}{l}-0.164 * * \\
(0.0699)\end{array}$ & $\begin{array}{l}-0.163^{* *} \\
(0.0699)\end{array}$ \\
\hline Family & $\begin{array}{l}0.0765 \\
(0.118)\end{array}$ & $\begin{array}{l}0.0756 \\
(0.118)\end{array}$ & $\begin{array}{l}0.0717 \\
(0.118)\end{array}$ & $\begin{array}{l}0.0651 \\
(0.118)\end{array}$ \\
\hline Illness2 & $\begin{array}{l}-0.0234 \\
(0.0647)\end{array}$ & $\begin{array}{l}-0.0228 \\
(0.0647)\end{array}$ & $\begin{array}{l}-0.0241 \\
(0.0647)\end{array}$ & $\begin{array}{l}-0.0228 \\
(0.0648)\end{array}$ \\
\hline Condition2 & $\begin{array}{l}-0.119 \\
(0.0801)\end{array}$ & $\begin{array}{l}-0.119 \\
(0.0801)\end{array}$ & $\begin{array}{l}-0.120 \\
(0.0801)\end{array}$ & $\begin{array}{l}-0.121 \\
(0.0801)\end{array}$ \\
\hline Community 1 & $\begin{array}{l}0.0410 \\
(0.0577)\end{array}$ & $\begin{array}{l}0.0431 \\
(0.0577)\end{array}$ & $\begin{array}{l}0.0443 \\
(0.0578)\end{array}$ & $\begin{array}{l}0.0457 \\
(0.0577)\end{array}$ \\
\hline Religion & $\begin{array}{l}-0.256 \\
(0.256)\end{array}$ & $\begin{array}{l}-0.257 \\
(0.256)\end{array}$ & $\begin{array}{l}-0.257 \\
(0.256)\end{array}$ & $\begin{array}{l}-0.261 \\
(0.256)\end{array}$ \\
\hline Personality 1 & $\begin{array}{l}0.0970 * * * \\
(0.0311)\end{array}$ & $\begin{array}{l}0.0969 * * * \\
(0.0311)\end{array}$ & $\begin{array}{l}0.0978 * * * \\
(0.0311)\end{array}$ & $\begin{array}{l}0.0990 * * * \\
(0.0311)\end{array}$ \\
\hline Personality 2 & $\begin{array}{l}-0.0370^{*} \\
(0.0220)\end{array}$ & $\begin{array}{l}-0.0370^{*} \\
(0.0220)\end{array}$ & $\begin{array}{l}-0.0370 * \\
(0.0220)\end{array}$ & $\begin{array}{l}-0.0370^{*} \\
(0.0220)\end{array}$ \\
\hline Personality 3 & $\begin{array}{l}-0.0499 * \\
(0.0285)\end{array}$ & $\begin{array}{l}-0.0495 * \\
(0.0285)\end{array}$ & $\begin{array}{l}-0.0497 * \\
(0.0285)\end{array}$ & $\begin{array}{l}-0.0494 * \\
(0.0285)\end{array}$ \\
\hline Personality4 & $\begin{array}{l}0.0285 \\
(0.0285)\end{array}$ & $\begin{array}{l}0.0284 \\
(0.0285)\end{array}$ & $\begin{array}{l}0.0293 \\
(0.0285)\end{array}$ & $\begin{array}{l}0.0290 \\
(0.0285)\end{array}$ \\
\hline Risk & $\begin{array}{l}0.0631 * * * \\
(0.0112)\end{array}$ & $\begin{array}{l}0.0630 * * * \\
(0.0112)\end{array}$ & $\begin{array}{l}0.0631 * * * \\
(0.0112)\end{array}$ & $\begin{array}{l}0.0631 * * * \\
(0.0112)\end{array}$ \\
\hline Circumstances & $\begin{array}{l}0.486^{* * * *} \\
(0.0176)\end{array}$ & $\begin{array}{l}0.486^{* * * *} \\
(0.0177)\end{array}$ & $\begin{array}{l}0.487 * * * \\
(0.0177)\end{array}$ & $\begin{array}{l}0.487 * * * \\
(0.0176)\end{array}$ \\
\hline Oblast 1 & $\begin{array}{l}0.824 * * * \\
(0.171)\end{array}$ & $\begin{array}{l}0.827 * * * \\
(0.171)\end{array}$ & $\begin{array}{l}0.827 * * * \\
(0.171)\end{array}$ & $\begin{array}{l}0.836 * * * \\
(0.171)\end{array}$ \\
\hline Oblast2 & $\begin{array}{l}0.363 * * \\
(0.180)\end{array}$ & $\begin{array}{l}0.367 * * \\
(0.180)\end{array}$ & $\begin{array}{l}0.371 * * \\
(0.180)\end{array}$ & $\begin{array}{l}0.377 * * \\
(0.180)\end{array}$ \\
\hline Oblast3 & $-0.424 * *$ & $-0.424 * *$ & $-0.425^{* *}$ & $-0.422 * *$ \\
\hline
\end{tabular}


Table 11 (continued)

\begin{tabular}{|c|c|c|c|c|}
\hline \multirow[t]{2}{*}{ Variables } & \multirow{2}{*}{$\begin{array}{l}\text { (1) } \\
\text { Index1 }\end{array}$} & \multirow{2}{*}{$\begin{array}{l}(2) \\
\text { Index } 2\end{array}$} & \multirow{2}{*}{$\begin{array}{l}(3) \\
\text { Index3 }\end{array}$} & \multirow{2}{*}{$\begin{array}{l}\text { (4) } \\
\text { Index4 }\end{array}$} \\
\hline & & & & \\
\hline & $(0.200)$ & $(0.200)$ & $(0.200)$ & $(0.200)$ \\
\hline \multirow[t]{2}{*}{ Oblast4 } & $1.108 * * *$ & $1.112 * * *$ & $1.114 * * *$ & $1.122 * * *$ \\
\hline & $(0.177)$ & $(0.177)$ & $(0.177)$ & $(0.177)$ \\
\hline \multirow[t]{2}{*}{ Oblast5 } & 0.290 & 0.294 & 0.291 & $0.305 *$ \\
\hline & $(0.180)$ & $(0.180)$ & $(0.180)$ & $(0.180)$ \\
\hline \multirow[t]{2}{*}{ Oblast6 } & $0.819^{* * *}$ & $0.823 * * *$ & $0.832 * * *$ & $0.845^{* * *}$ \\
\hline & $(0.191)$ & $(0.191)$ & $(0.191)$ & $(0.191)$ \\
\hline \multirow[t]{2}{*}{ Oblast7 } & $0.706^{* * *}$ & $0.708 * * *$ & $0.708 * * *$ & $0.719 * * *$ \\
\hline & $(0.169)$ & $(0.169)$ & (0.169) & (0.169) \\
\hline \multirow[t]{2}{*}{ Oblast8 } & $0.427 * * *$ & $0.429 * * *$ & $0.434 * * *$ & $0.441 * * *$ \\
\hline & $(0.153)$ & $(0.153)$ & $(0.153)$ & $(0.153)$ \\
\hline \multirow[t]{2}{*}{ Constant } & $3.441 * * *$ & $3.440 * * *$ & $3.427 * * *$ & $3.433 * * *$ \\
\hline & $(0.447)$ & $(0.448)$ & $(0.449)$ & $(0.449)$ \\
\hline Observations & 2460 & 2460 & 2460 & 2460 \\
\hline R-squared & 0.358 & 0.358 & 0.358 & 0.358 \\
\hline
\end{tabular}

Standard errors in parentheses

$* * * p<0.01 ; * * p<0.05 ;{ }^{*} p<0.1$ 
Table 12 Full results from ordered probit analysis of wage and hours-worked sub-indices

\begin{tabular}{|c|c|c|c|c|}
\hline \multirow[t]{2}{*}{ Variables } & (1) & (2) & (3) & (4) \\
\hline & Wage-hours1 & Wage-hours2 & Wage-hours3 & Wage-hours 4 \\
\hline \multirow[t]{2}{*}{ Wage-hours } & 0.00142 & 0.00132 & 0.00133 & 0.00125 \\
\hline & $(0.00108)$ & $(0.00105)$ & $(0.00108)$ & $(0.00120)$ \\
\hline \multirow[t]{2}{*}{ Age } & $-0.0303 * *$ & $-0.0304 * *$ & $-0.0304 * *$ & $-0.0303 * *$ \\
\hline & $(0.0140)$ & $(0.0140)$ & $(0.0140)$ & $(0.0140)$ \\
\hline \multirow[t]{2}{*}{ Age2 } & $0.0323^{*}$ & $0.0324 *$ & $0.0324 *$ & $0.0323^{*}$ \\
\hline & $(0.0177)$ & $(0.0177)$ & $(0.0177)$ & $(0.0177)$ \\
\hline \multirow[t]{2}{*}{ Gender } & -0.0376 & -0.0374 & -0.0373 & -0.0354 \\
\hline & $(0.0476)$ & $(0.0476)$ & $(0.0476)$ & $(0.0476)$ \\
\hline \multirow[t]{2}{*}{ Ethnicity } & 0.0441 & 0.0439 & 0.0438 & 0.0434 \\
\hline & $(0.0510)$ & $(0.0510)$ & $(0.0510)$ & $(0.0510)$ \\
\hline \multirow[t]{2}{*}{ Urban } & -0.0650 & -0.0649 & -0.0648 & -0.0633 \\
\hline & $(0.0656)$ & $(0.0656)$ & $(0.0656)$ & $(0.0656)$ \\
\hline \multirow[t]{2}{*}{ Education } & $0.0394 * *$ & $0.0395^{* *}$ & $0.0396 * *$ & $0.0400 * *$ \\
\hline & $(0.0175)$ & $(0.0175)$ & $(0.0175)$ & $(0.0175)$ \\
\hline \multirow[t]{2}{*}{ Employer } & 0.0353 & 0.0358 & 0.0361 & 0.0403 \\
\hline & $(0.222)$ & $(0.222)$ & $(0.222)$ & $(0.222)$ \\
\hline \multirow[t]{2}{*}{ Wageworker } & $-0.113 * *$ & $-0.113 * *$ & $-0.113 * *$ & $-0.114 * *$ \\
\hline & $(0.0516)$ & $(0.0516)$ & $(0.0516)$ & $(0.0516)$ \\
\hline \multirow[t]{2}{*}{ Family } & 0.0223 & 0.0218 & 0.0215 & 0.0183 \\
\hline & $(0.0874)$ & $(0.0874)$ & $(0.0874)$ & $(0.0874)$ \\
\hline \multirow[t]{2}{*}{ Illness2 } & -0.0277 & -0.0276 & -0.0276 & -0.0272 \\
\hline & $(0.0479)$ & $(0.0479)$ & $(0.0479)$ & $(0.0479)$ \\
\hline \multirow[t]{2}{*}{ Condition2 } & -0.0854 & -0.0855 & -0.0855 & -0.0864 \\
\hline & $(0.0591)$ & $(0.0591)$ & $(0.0591)$ & $(0.0591)$ \\
\hline \multirow[t]{2}{*}{ Community1 } & 0.0433 & 0.0435 & 0.0436 & 0.0435 \\
\hline & $(0.0426)$ & $(0.0426)$ & $(0.0426)$ & $(0.0426)$ \\
\hline \multirow[t]{2}{*}{ Religion } & -0.180 & -0.180 & -0.180 & -0.182 \\
\hline & $(0.190)$ & $(0.190)$ & $(0.190)$ & $(0.190)$ \\
\hline \multirow[t]{2}{*}{ Personality 1} & $0.0764 * * *$ & $0.0765 * * *$ & $0.0765^{* * *}$ & $0.0768 * * *$ \\
\hline & $(0.0230)$ & $(0.0230)$ & $(0.0230)$ & $(0.0230)$ \\
\hline \multirow[t]{2}{*}{ Personality 2} & $-0.0292 *$ & $-0.0292 *$ & $-0.0292^{*}$ & $-0.0292^{*}$ \\
\hline & $(0.0163)$ & $(0.0163)$ & $(0.0163)$ & $(0.0163)$ \\
\hline \multirow[t]{2}{*}{ Personality 3} & -0.0332 & -0.0331 & -0.0331 & -0.0330 \\
\hline & $(0.0210)$ & $(0.0210)$ & $(0.0210)$ & $(0.0210)$ \\
\hline \multirow[t]{2}{*}{ Personality4 } & 0.0248 & 0.0249 & 0.0250 & 0.0251 \\
\hline & $(0.0211)$ & $(0.0211)$ & $(0.0211)$ & $(0.0211)$ \\
\hline \multirow[t]{2}{*}{ Risk } & $0.0484 * * *$ & $0.0484 * * *$ & $0.0484 * * *$ & $0.0485 * * *$ \\
\hline & $(0.00840)$ & $(0.00840)$ & $(0.00840)$ & $(0.00840)$ \\
\hline \multirow[t]{2}{*}{ Circumstances } & $0.361 * * *$ & $0.361 * * *$ & $0.361 * * *$ & $0.361 * * *$ \\
\hline & $(0.0141)$ & $(0.0141)$ & $(0.0141)$ & $(0.0141)$ \\
\hline \multirow[t]{2}{*}{ Oblast1 } & $0.606^{* * * *}$ & $0.606^{* * * *}$ & $0.607 * * *$ & $0.606 * * *$ \\
\hline & $(0.126)$ & $(0.126)$ & $(0.126)$ & $(0.126)$ \\
\hline Oblast2 & $0.292 * *$ & $0.292 * *$ & $0.292 * *$ & $0.291 * *$ \\
\hline
\end{tabular}


Table 12 (continued)

\begin{tabular}{|c|c|c|c|c|}
\hline \multirow[t]{2}{*}{ Variables } & \multirow{2}{*}{$\begin{array}{l}\text { (1) } \\
\text { Wage-hours1 }\end{array}$} & \multirow{2}{*}{$\begin{array}{l}\text { (2) } \\
\text { Wage-hours2 }\end{array}$} & \multirow{2}{*}{$\begin{array}{l}\text { (3) } \\
\text { Wage-hours3 }\end{array}$} & \multirow{2}{*}{$\begin{array}{l}\text { (4) } \\
\text { Wage-hours4 }\end{array}$} \\
\hline & & & & \\
\hline & $(0.132)$ & $(0.132)$ & $(0.132)$ & $(0.132)$ \\
\hline \multirow[t]{2}{*}{ Oblast3 } & $-0.308 * *$ & $-0.307 * *$ & $-0.307 * *$ & $-0.305^{* *}$ \\
\hline & $(0.147)$ & $(0.147)$ & $(0.147)$ & $(0.147)$ \\
\hline \multirow[t]{2}{*}{ Oblast4 } & $0.875^{* * *}$ & $0.876^{* * *}$ & $0.876^{* * *}$ & $0.877 * * *$ \\
\hline & $(0.131)$ & $(0.131)$ & $(0.131)$ & $(0.131)$ \\
\hline \multirow[t]{2}{*}{ Oblast5 } & 0.205 & 0.205 & 0.206 & 0.207 \\
\hline & $(0.132)$ & $(0.132)$ & $(0.132)$ & $(0.132)$ \\
\hline \multirow[t]{2}{*}{ Oblast6 } & $0.622 * * *$ & $0.623^{* * *}$ & $0.623^{* * *}$ & $0.625^{* * *}$ \\
\hline & $(0.140)$ & $(0.140)$ & $(0.140)$ & $(0.140)$ \\
\hline \multirow[t]{2}{*}{ Oblast7 } & $0.519^{* * *}$ & $0.520^{* * *}$ & $0.520 * * *$ & $0.523 * * *$ \\
\hline & $(0.124)$ & $(0.124)$ & $(0.124)$ & $(0.124)$ \\
\hline \multirow[t]{2}{*}{ Oblast8 } & $0.343 * * *$ & $0.344 * * *$ & $0.345^{* * *}$ & $0.346^{* * *}$ \\
\hline & $(0.112)$ & $(0.112)$ & $(0.112)$ & $(0.112)$ \\
\hline \multirow[t]{2}{*}{ Constant cut 1} & $-1.626^{* * *}$ & $-1.629 * * *$ & $-1.628 * * *$ & $-1.624 * * *$ \\
\hline & $(0.461)$ & $(0.461)$ & $(0.461)$ & $(0.461)$ \\
\hline \multirow[t]{2}{*}{ Constant cut 2} & $-0.906 * *$ & $-0.910 * *$ & $-0.909 * *$ & $-0.905^{* *}$ \\
\hline & $(0.356)$ & $(0.356)$ & $(0.356)$ & $(0.356)$ \\
\hline \multirow[t]{2}{*}{ Constant cut 3} & $-0.674 *$ & $-0.678 * *$ & $-0.677 * *$ & $-0.673^{*}$ \\
\hline & $(0.345)$ & $(0.345)$ & $(0.345)$ & $(0.346)$ \\
\hline \multirow[t]{2}{*}{ Constant cut 4} & 0.102 & 0.0975 & 0.0984 & 0.103 \\
\hline & $(0.332)$ & $(0.332)$ & $(0.332)$ & $(0.333)$ \\
\hline \multirow[t]{2}{*}{ Constant cut5 } & $0.675^{* *}$ & $0.671^{* *}$ & $0.672 * *$ & $0.676^{* *}$ \\
\hline & $(0.331)$ & $(0.331)$ & $(0.331)$ & $(0.331)$ \\
\hline \multirow[t]{2}{*}{ Constant cut6 } & $1.518 * * *$ & $1.513 * * *$ & $1.514 * * *$ & $1.518 * * *$ \\
\hline & $(0.331)$ & $(0.331)$ & $(0.331)$ & $(0.331)$ \\
\hline \multirow[t]{2}{*}{ Constant cut7 } & $2.210 * * *$ & $2.206^{* * *}$ & $2.206^{* * *}$ & $2.210 * * *$ \\
\hline & $(0.332)$ & $(0.331)$ & $(0.331)$ & $(0.332)$ \\
\hline \multirow[t]{2}{*}{ Constant cut 8} & $2.932 * * *$ & $2.928 * * *$ & $2.929 * * *$ & $2.933 * * *$ \\
\hline & $(0.333)$ & $(0.333)$ & $(0.333)$ & $(0.333)$ \\
\hline \multirow[t]{2}{*}{ Constant cut 9} & $3.692 * * *$ & $3.688^{* * * *}$ & $3.689 * * *$ & $3.693 * * *$ \\
\hline & $(0.334)$ & $(0.334)$ & $(0.334)$ & $(0.334)$ \\
\hline \multirow[t]{2}{*}{ Constant cut 10} & $4.185^{* * *}$ & $4.181 * * *$ & $4.182 * * *$ & $4.186^{* * *}$ \\
\hline & $(0.336)$ & $(0.336)$ & $(0.336)$ & $(0.336)$ \\
\hline Observations & 2460 & 2460 & 2460 & 2460 \\
\hline
\end{tabular}

Standard errors in parentheses

$*^{* * *} p<0.01 ; * * p<0.05 ; * p<0.1$ 
Table 13 Full results from ordered probit analyses of full indices

\begin{tabular}{|c|c|c|c|c|}
\hline Variables & $\begin{array}{l}\text { (1) } \\
\text { Index1 }\end{array}$ & $\begin{array}{l}(2) \\
\text { Index2 }\end{array}$ & $\begin{array}{l}\text { (3) } \\
\text { Index3 }\end{array}$ & $\begin{array}{l}(4) \\
\text { Index4 }\end{array}$ \\
\hline Index & $\begin{array}{l}0.00584 * * * \\
(0.00182)\end{array}$ & $\begin{array}{l}0.00565 \text { *** } \\
(0.00187)\end{array}$ & $\begin{array}{l}0.00521 * * * \\
(0.00190)\end{array}$ & $\begin{array}{l}0.00575 * * * \\
(0.00218)\end{array}$ \\
\hline Age & $\begin{array}{l}-0.0326^{* *} \\
(0.0140)\end{array}$ & $\begin{array}{l}-0.0329 * * \\
(0.0140)\end{array}$ & $\begin{array}{l}-0.0317^{* *} \\
(0.0140)\end{array}$ & $\begin{array}{l}-0.0322 * * \\
(0.0140)\end{array}$ \\
\hline Age2 & $\begin{array}{l}0.0339 * \\
(0.0177)\end{array}$ & $\begin{array}{l}0.0342 * \\
(0.0177)\end{array}$ & $\begin{array}{l}0.0331 * \\
(0.0177)\end{array}$ & $\begin{array}{l}0.0336^{*} \\
(0.0177)\end{array}$ \\
\hline Gender & $\begin{array}{l}-0.0324 \\
(0.0469)\end{array}$ & $\begin{array}{l}-0.0350 \\
(0.0470)\end{array}$ & $\begin{array}{l}-0.0333 \\
(0.0469)\end{array}$ & $\begin{array}{l}-0.0329 \\
(0.0469)\end{array}$ \\
\hline Ethnicity & $\begin{array}{l}0.0443 \\
(0.0510)\end{array}$ & $\begin{array}{l}0.0443 \\
(0.0510)\end{array}$ & $\begin{array}{l}0.0438 \\
(0.0510)\end{array}$ & $\begin{array}{l}0.0451 \\
(0.0510)\end{array}$ \\
\hline Urban & $\begin{array}{l}-0.0682 \\
(0.0655)\end{array}$ & $\begin{array}{l}-0.0679 \\
(0.0655)\end{array}$ & $\begin{array}{l}-0.0687 \\
(0.0655)\end{array}$ & $\begin{array}{l}-0.0651 \\
(0.0655)\end{array}$ \\
\hline Education & $\begin{array}{l}0.0260 \\
(0.0181)\end{array}$ & $\begin{array}{l}0.0273 \\
(0.0181)\end{array}$ & $\begin{array}{l}0.0285 \\
(0.0181)\end{array}$ & $\begin{array}{l}0.0293 \\
(0.0181)\end{array}$ \\
\hline Employer & $\begin{array}{l}0.00545 \\
(0.223)\end{array}$ & $\begin{array}{l}0.00803 \\
(0.223)\end{array}$ & $\begin{array}{l}0.00947 \\
(0.223)\end{array}$ & $\begin{array}{l}0.0172 \\
(0.223)\end{array}$ \\
\hline Wageworker & $\begin{array}{l}-0.120 * * \\
(0.0517)\end{array}$ & $\begin{array}{l}-0.118^{* *} \\
(0.0516)\end{array}$ & $\begin{array}{l}-0.119 * * \\
(0.0517)\end{array}$ & $\begin{array}{l}-0.117 * * \\
(0.0516)\end{array}$ \\
\hline Family & $\begin{array}{l}0.0476 \\
(0.0872)\end{array}$ & $\begin{array}{l}0.0469 \\
(0.0873)\end{array}$ & $\begin{array}{l}0.0441 \\
(0.0874)\end{array}$ & $\begin{array}{l}0.0391 \\
(0.0872)\end{array}$ \\
\hline Illness2 & $\begin{array}{l}-0.0269 \\
(0.0479)\end{array}$ & $\begin{array}{l}-0.0265 \\
(0.0479)\end{array}$ & $\begin{array}{l}-0.0275 \\
(0.0479)\end{array}$ & $\begin{array}{l}-0.0264 \\
(0.0479)\end{array}$ \\
\hline Condition 2 & $\begin{array}{l}-0.0841 \\
(0.0591)\end{array}$ & $\begin{array}{l}-0.0841 \\
(0.0591)\end{array}$ & $\begin{array}{l}-0.0846 \\
(0.0591)\end{array}$ & $\begin{array}{l}-0.0854 \\
(0.0591)\end{array}$ \\
\hline Community 1 & $\begin{array}{l}0.0297 \\
(0.0428)\end{array}$ & $\begin{array}{l}0.0313 \\
(0.0428)\end{array}$ & $\begin{array}{l}0.0322 \\
(0.0428)\end{array}$ & $\begin{array}{l}0.0333 \\
(0.0428)\end{array}$ \\
\hline Religion & $\begin{array}{l}-0.176 \\
(0.190)\end{array}$ & $\begin{array}{l}-0.176 \\
(0.190)\end{array}$ & $\begin{array}{l}-0.176 \\
(0.190)\end{array}$ & $\begin{array}{l}-0.179 \\
(0.190)\end{array}$ \\
\hline Personality1 & $\begin{array}{l}0.0746 * * * \\
(0.0230)\end{array}$ & $\begin{array}{l}0.0745 * * * \\
(0.0230)\end{array}$ & $\begin{array}{l}0.0751 * * * \\
(0.0230)\end{array}$ & $\begin{array}{l}0.0761 * * * \\
(0.0230)\end{array}$ \\
\hline Personality 2 & $\begin{array}{l}-0.0293 * \\
(0.0163)\end{array}$ & $\begin{array}{l}-0.0293 * \\
(0.0163)\end{array}$ & $\begin{array}{l}-0.0293 * \\
(0.0163)\end{array}$ & $\begin{array}{l}-0.0293 * \\
(0.0163)\end{array}$ \\
\hline Personality 3 & $\begin{array}{l}-0.0353^{*} \\
(0.0210)\end{array}$ & $\begin{array}{l}-0.0351 * \\
(0.0210)\end{array}$ & $\begin{array}{l}-0.0352 * \\
(0.0210)\end{array}$ & $\begin{array}{l}-0.0350 * \\
(0.0210)\end{array}$ \\
\hline Personality 4 & $\begin{array}{l}0.0232 \\
(0.0211)\end{array}$ & $\begin{array}{l}0.0231 \\
(0.0211)\end{array}$ & $\begin{array}{l}0.0238 \\
(0.0211)\end{array}$ & $\begin{array}{l}0.0236 \\
(0.0211)\end{array}$ \\
\hline Risk & $\begin{array}{l}0.0484 * * * \\
(0.00839)\end{array}$ & $\begin{array}{l}0.0484 * * * \\
(0.00839)\end{array}$ & $\begin{array}{l}0.0484 * * * \\
(0.00839)\end{array}$ & $\begin{array}{l}0.0483 * * * \\
(0.00839)\end{array}$ \\
\hline Circumstances & $\begin{array}{l}0.360 * * * \\
(0.0141)\end{array}$ & $\begin{array}{l}0.360 * * * \\
(0.0141)\end{array}$ & $\begin{array}{l}0.359 * * * \\
(0.0141)\end{array}$ & $\begin{array}{l}0.360 * * * \\
(0.0141)\end{array}$ \\
\hline Oblast 1 & $\begin{array}{l}0.608 * * * \\
(0.126)\end{array}$ & $\begin{array}{l}0.610 * * * \\
(0.126)\end{array}$ & $\begin{array}{l}0.610 * * * \\
(0.126)\end{array}$ & $\begin{array}{l}0.616^{* * *} \\
(0.127)\end{array}$ \\
\hline Oblast 2 & $\begin{array}{l}0.267 * * \\
(0.133)\end{array}$ & $\begin{array}{l}0.270 * * \\
(0.133)\end{array}$ & $\begin{array}{l}0.273 * * \\
(0.132)\end{array}$ & $\begin{array}{l}0.278 * * \\
(0.132)\end{array}$ \\
\hline Oblast 3 & $-0.314 * *$ & $-0.313 * *$ & $-0.314 * *$ & $-0.311^{* *}$ \\
\hline
\end{tabular}


Table 13 (continued)

\begin{tabular}{|c|c|c|c|c|}
\hline Variables & $\begin{array}{l}\text { (1) } \\
\text { Index1 }\end{array}$ & $\begin{array}{l}\text { (2) } \\
\text { Index2 }\end{array}$ & $\begin{array}{l}\text { (3) } \\
\text { Index3 }\end{array}$ & $\begin{array}{l}\text { (4) } \\
\text { Index4 }\end{array}$ \\
\hline & $(0.147)$ & $(0.147)$ & $(0.147)$ & $(0.147)$ \\
\hline Oblast4 & $\begin{array}{l}0.869 * * * \\
(0.131)\end{array}$ & $\begin{array}{l}0.871^{* * *} \\
(0.131)\end{array}$ & $\begin{array}{l}0.872 * * * \\
(0.131)\end{array}$ & $\begin{array}{l}0.878 * * * \\
(0.131)\end{array}$ \\
\hline Oblast5 & $\begin{array}{l}0.198 \\
(0.132)\end{array}$ & $\begin{array}{l}0.201 \\
(0.132)\end{array}$ & $\begin{array}{l}0.199 \\
(0.132)\end{array}$ & $\begin{array}{l}0.209 \\
(0.132)\end{array}$ \\
\hline Oblast6 & $\begin{array}{l}0.591 * * * \\
(0.141)\end{array}$ & $\begin{array}{l}0.594 * * * \\
(0.141)\end{array}$ & $\begin{array}{l}0.600^{* * *} \\
(0.140)\end{array}$ & $\begin{array}{l}0.610 * * * \\
(0.140)\end{array}$ \\
\hline Oblast7 & $\begin{array}{l}0.519 * * * \\
(0.124)\end{array}$ & $\begin{array}{l}0.520 * * * \\
(0.124)\end{array}$ & $\begin{array}{l}0.519 * * * \\
(0.124)\end{array}$ & $\begin{array}{l}0.528 * * * \\
(0.124)\end{array}$ \\
\hline Oblast8 & $\begin{array}{l}0.328 * * * \\
(0.112)\end{array}$ & $\begin{array}{l}0.330^{* * *} \\
(0.112)\end{array}$ & $\begin{array}{l}0.333^{* * * *} \\
(0.112)\end{array}$ & $\begin{array}{l}0.339^{* * * *} \\
(0.112)\end{array}$ \\
\hline Constant cut 1 & $\begin{array}{l}-1.545^{* * *} \\
(0.461)\end{array}$ & $\begin{array}{l}-1.545^{* * *} \\
(0.461)\end{array}$ & $\begin{array}{l}-1.534 * * * \\
(0.462)\end{array}$ & $\begin{array}{l}-1.543 * * * \\
(0.462)\end{array}$ \\
\hline Constant cut2 & $\begin{array}{l}-0.829^{* *} \\
(0.357)\end{array}$ & $\begin{array}{l}-0.829 * * \\
(0.357)\end{array}$ & $\begin{array}{l}-0.818^{* *} \\
(0.358)\end{array}$ & $\begin{array}{l}-0.826^{* *} \\
(0.358)\end{array}$ \\
\hline Constant cut3 & $\begin{array}{l}-0.597 * \\
(0.347)\end{array}$ & $\begin{array}{l}-0.597^{*} \\
(0.347)\end{array}$ & $\begin{array}{l}-0.586^{*} \\
(0.347)\end{array}$ & $\begin{array}{l}-0.593^{*} \\
(0.347)\end{array}$ \\
\hline Constant cut 4 & $\begin{array}{l}0.179 \\
(0.334)\end{array}$ & $\begin{array}{l}0.180 \\
(0.334)\end{array}$ & $\begin{array}{l}0.190 \\
(0.334)\end{array}$ & $\begin{array}{l}0.184 \\
(0.334)\end{array}$ \\
\hline Constant cut5 & $\begin{array}{l}0.753^{* *} \\
(0.332)\end{array}$ & $\begin{array}{l}0.753 * * \\
(0.332)\end{array}$ & $\begin{array}{l}0.763^{* *} \\
(0.333)\end{array}$ & $\begin{array}{l}0.757 * * \\
(0.333)\end{array}$ \\
\hline Constant cut6 & $\begin{array}{l}1.598 * * * \\
(0.332)\end{array}$ & $\begin{array}{l}1.598^{* * *} \\
(0.332)\end{array}$ & $\begin{array}{l}1.607 * * * \\
(0.333)\end{array}$ & $\begin{array}{l}1.601 * * * \\
(0.333)\end{array}$ \\
\hline Constant cut7 & $\begin{array}{l}2.292 * * * \\
(0.333)\end{array}$ & $\begin{array}{l}2.291 * * * \\
(0.333)\end{array}$ & $\begin{array}{l}2.300^{* * *} \\
(0.334)\end{array}$ & $\begin{array}{l}2.294 * * * \\
(0.333)\end{array}$ \\
\hline Constant cut8 & $\begin{array}{l}3.016 * * * \\
(0.334)\end{array}$ & $\begin{array}{l}3.015 * * * \\
(0.334)\end{array}$ & $\begin{array}{l}3.024 * * * \\
(0.335)\end{array}$ & $\begin{array}{l}3.018 * * * \\
(0.335)\end{array}$ \\
\hline Constant cut9 & $\begin{array}{l}3.777 * * * \\
(0.336)\end{array}$ & $\begin{array}{l}3.776 * * * \\
(0.336)\end{array}$ & $\begin{array}{l}3.785 * * * \\
(0.336)\end{array}$ & $\begin{array}{l}3.778 * * * \\
(0.336)\end{array}$ \\
\hline Constant cut 10 & $\begin{array}{l}4.270 * * * \\
(0.337)\end{array}$ & $\begin{array}{l}4.270^{* * * *} \\
(0.337)\end{array}$ & $\begin{array}{l}4.278 * * * \\
(0.338)\end{array}$ & $\begin{array}{l}4.272 * * * \\
(0.338)\end{array}$ \\
\hline Observations & 2460 & 2460 & 2460 & 2460 \\
\hline
\end{tabular}

Standard errors in parentheses

$* * * p<0.01 ; * * p<0.05 ; * p<0.1$ 
Table 14 Full results from OLS analyses of age-weighted wage and hours worked sub-indices

\begin{tabular}{|c|c|c|c|c|}
\hline \multirow[t]{2}{*}{ Variables } & (1) & (2) & (3) & (4) \\
\hline & Awage-hours1 & Awage-hours2 & Awage-hours3 & Awage-hours4 \\
\hline \multirow[t]{2}{*}{ Age-wage-hours } & 0.000881 & 0.000770 & 0.000744 & 0.000639 \\
\hline & $(0.00130)$ & $(0.00126)$ & $(0.00130)$ & $(0.00146)$ \\
\hline \multirow[t]{2}{*}{ Age } & $-0.0369^{*}$ & $-0.0374 *$ & $-0.0375^{*}$ & $-0.0379 *$ \\
\hline & $(0.0197)$ & $(0.0197)$ & $(0.0197)$ & $(0.0199)$ \\
\hline \multirow[t]{2}{*}{ Age2 } & 0.0400 & $0.0405 *$ & $0.0406^{*}$ & $0.0409 *$ \\
\hline & $(0.0244)$ & $(0.0243)$ & $(0.0243)$ & $(0.0244)$ \\
\hline \multirow[t]{2}{*}{ Gender } & -0.0414 & -0.0410 & -0.0407 & -0.0392 \\
\hline & $(0.0643)$ & $(0.0643)$ & $(0.0643)$ & $(0.0643)$ \\
\hline \multirow[t]{2}{*}{ Ethnicity } & 0.0538 & 0.0536 & 0.0535 & 0.0533 \\
\hline & $(0.0692)$ & $(0.0692)$ & $(0.0692)$ & $(0.0692)$ \\
\hline \multirow[t]{2}{*}{ Urban } & -0.0718 & -0.0715 & -0.0713 & -0.0700 \\
\hline & $(0.0888)$ & $(0.0888)$ & $(0.0888)$ & $(0.0887)$ \\
\hline \multirow[t]{2}{*}{ Education } & $0.0550 * *$ & $0.0552 * *$ & $0.0553 * *$ & $0.0556 * *$ \\
\hline & $(0.0236)$ & $(0.0237)$ & $(0.0237)$ & $(0.0237)$ \\
\hline \multirow[t]{2}{*}{ Employer } & 0.0297 & 0.0304 & 0.0308 & 0.0329 \\
\hline & $(0.296)$ & $(0.296)$ & $(0.296)$ & $(0.296)$ \\
\hline \multirow[t]{2}{*}{ Wageworker } & $-0.157 * *$ & $-0.156^{* *}$ & $-0.156^{* *}$ & $-0.157 * *$ \\
\hline & $(0.0700)$ & $(0.0700)$ & $(0.0700)$ & $(0.0700)$ \\
\hline \multirow[t]{2}{*}{ Family } & 0.0315 & 0.0304 & 0.0297 & 0.0269 \\
\hline & $(0.118)$ & $(0.119)$ & (0.119) & $(0.119)$ \\
\hline \multirow[t]{2}{*}{ Illness2 } & -0.0246 & -0.0245 & -0.0245 & -0.0243 \\
\hline & $(0.0648)$ & $(0.0648)$ & $(0.0648)$ & $(0.0648)$ \\
\hline \multirow[t]{2}{*}{ Condition 2} & -0.122 & -0.122 & -0.122 & -0.123 \\
\hline & $(0.0803)$ & $(0.0803)$ & $(0.0803)$ & $(0.0802)$ \\
\hline \multirow[t]{2}{*}{ Community1 } & 0.0611 & 0.0613 & 0.0614 & 0.0615 \\
\hline & $(0.0575)$ & $(0.0575)$ & $(0.0575)$ & $(0.0575)$ \\
\hline \multirow[t]{2}{*}{ Religion } & -0.267 & -0.268 & -0.268 & -0.269 \\
\hline & $(0.257)$ & $(0.257)$ & $(0.257)$ & $(0.257)$ \\
\hline \multirow[t]{2}{*}{ Personality 1} & $0.101 * * *$ & $0.101 * * *$ & $0.101 * * *$ & $0.101 * * *$ \\
\hline & $(0.0312)$ & $(0.0312)$ & $(0.0312)$ & $(0.0312)$ \\
\hline \multirow[t]{2}{*}{ Personality2 } & $-0.0364^{*}$ & $-0.0364 *$ & $-0.0364 *$ & $-0.0364 *$ \\
\hline & $(0.0220)$ & $(0.0220)$ & $(0.0220)$ & $(0.0220)$ \\
\hline \multirow[t]{2}{*}{ Personality 3} & -0.0464 & -0.0463 & -0.0463 & -0.0461 \\
\hline & $(0.0285)$ & $(0.0285)$ & $(0.0285)$ & $(0.0285)$ \\
\hline \multirow[t]{2}{*}{ Personality4 } & 0.0321 & 0.0323 & 0.0324 & 0.0325 \\
\hline & $(0.0286)$ & $(0.0286)$ & $(0.0286)$ & $(0.0286)$ \\
\hline \multirow[t]{2}{*}{ Risk } & $0.0636^{* * *}$ & $0.0636^{* * *}$ & $0.0636^{* * * *}$ & $0.0637 * * *$ \\
\hline & $(0.0112)$ & $(0.0112)$ & $(0.0112)$ & $(0.0112)$ \\
\hline \multirow[t]{2}{*}{ Circumstances } & $0.490 * * *$ & $0.490 * * *$ & $0.490 * * *$ & $0.490 * * *$ \\
\hline & $(0.0177)$ & $(0.0177)$ & $(0.0177)$ & $(0.0177)$ \\
\hline \multirow[t]{2}{*}{ Oblast1 } & $0.820 * * *$ & $0.821 * * *$ & $0.821 * * *$ & $0.820 * * *$ \\
\hline & $(0.171)$ & $(0.171)$ & $(0.171)$ & $(0.171)$ \\
\hline Oblast 2 & $0.397 * *$ & $0.397 * *$ & $0.397 * *$ & $0.397 * *$ \\
\hline
\end{tabular}


Table 14 (continued)

\begin{tabular}{lllll}
\hline Variables & $(1)$ & $(2)$ & $(3)$ & $(4)$ \\
& Awage-hours1 & Awage-hours2 & Awage-hours3 & Awage-hours4 \\
\hline \multirow{2}{*}{ Oblast3 } & $(0.180)$ & $(0.180)$ & $(0.180)$ & $(0.180)$ \\
& $-0.413^{* *}$ & $-0.413^{* *}$ & $-0.413^{* *}$ & $-0.411^{* *}$ \\
Oblast4 & $(0.200)$ & $(0.200)$ & $(0.200)$ & $(0.200)$ \\
& $1.127^{* * *}$ & $1.128^{* * *}$ & $1.128^{* * *}$ & $1.129^{* * *}$ \\
Oblast5 & $(0.177)$ & $(0.177)$ & $(0.177)$ & $(0.177)$ \\
& $0.303^{*}$ & $0.303^{*}$ & $0.304^{*}$ & $0.305^{*}$ \\
Oblast6 & $(0.180)$ & $(0.180)$ & $(0.180)$ & $(0.180)$ \\
& $0.872^{* * *}$ & $0.873^{* * *}$ & $0.874^{* * *}$ & $0.876^{* * *}$ \\
Oblast7 & $(0.191)$ & $(0.191)$ & $(0.191)$ & $(0.191)$ \\
& $0.717^{* * *}$ & $0.718^{* * *}$ & $0.719^{* * *}$ & $0.721^{* * *}$ \\
Oblast8 & $(0.170)$ & $(0.170)$ & $(0.170)$ & $(0.169)$ \\
& $0.458^{* * *}$ & $0.459^{* * *}$ & $0.460^{* * *}$ & $0.462^{* * *}$ \\
Constant & $(0.153)$ & $(0.153)$ & $(0.153)$ & $(0.153)$ \\
& $3.441^{* * *}$ & $3.458^{* * *}$ & $3.461^{* * *}$ & $3.471^{* * *}$ \\
Observations & $(0.477)$ & $(0.474)$ & $(0.475)$ & $(0.485)$ \\
R-squared & 2460 & 2460 & 2460 & 2460 \\
\hline
\end{tabular}

Standard errors in parentheses

$* * * p<0.01 ; * * p<0.05 ; * p<0.1$ 
Table 15 Full result from OLS analyses of age-weighted full indices

\begin{tabular}{|c|c|c|c|c|}
\hline Variables & $\begin{array}{l}\text { (1) } \\
\text { Age-index1 }\end{array}$ & $\begin{array}{l}\text { (2) } \\
\text { Age-index2 }\end{array}$ & $\begin{array}{l}\text { (3) } \\
\text { Age-index3 }\end{array}$ & $\begin{array}{l}\text { (4) } \\
\text { Age-index4 }\end{array}$ \\
\hline Age-index & $\begin{array}{l}0.00612^{* * *} \\
(0.00222)\end{array}$ & $\begin{array}{l}0.00579 * * \\
(0.00228)\end{array}$ & $\begin{array}{l}0.00515^{* *} \\
(0.00230)\end{array}$ & $\begin{array}{l}0.00590 * * \\
(0.00266)\end{array}$ \\
\hline Age & $\begin{array}{l}-0.0173 \\
(0.0207)\end{array}$ & $\begin{array}{l}-0.0184 \\
(0.0208)\end{array}$ & $\begin{array}{l}-0.0195 \\
(0.0211)\end{array}$ & $\begin{array}{l}-0.0210 \\
(0.0209)\end{array}$ \\
\hline Age2 & $\begin{array}{l}0.0243 \\
(0.0248)\end{array}$ & $\begin{array}{l}0.0253 \\
(0.0249)\end{array}$ & $\begin{array}{l}0.0257 \\
(0.0251)\end{array}$ & $\begin{array}{l}0.0271 \\
(0.0250)\end{array}$ \\
\hline Gender & $\begin{array}{l}-0.0378 \\
(0.0635)\end{array}$ & $\begin{array}{l}-0.0407 \\
(0.0635)\end{array}$ & $\begin{array}{l}-0.0390 \\
(0.0636)\end{array}$ & $\begin{array}{l}-0.0390 \\
(0.0636)\end{array}$ \\
\hline Ethnicity & $\begin{array}{l}0.0513 \\
(0.0691)\end{array}$ & $\begin{array}{l}0.0517 \\
(0.0691)\end{array}$ & $\begin{array}{l}0.0512 \\
(0.0691)\end{array}$ & $\begin{array}{l}0.0525 \\
(0.0691)\end{array}$ \\
\hline Urban & $\begin{array}{l}-0.0785 \\
(0.0885)\end{array}$ & $\begin{array}{l}-0.0781 \\
(0.0885)\end{array}$ & $\begin{array}{l}-0.0783 \\
(0.0886)\end{array}$ & $\begin{array}{l}-0.0749 \\
(0.0885)\end{array}$ \\
\hline Education & $\begin{array}{l}0.0397 \\
(0.0243)\end{array}$ & $\begin{array}{l}0.0415^{*} \\
(0.0242)\end{array}$ & $\begin{array}{l}0.0433^{*} \\
(0.0243)\end{array}$ & $\begin{array}{l}0.0436^{*} \\
(0.0242)\end{array}$ \\
\hline Employer & $\begin{array}{l}-0.00420 \\
(0.295)\end{array}$ & $\begin{array}{l}-0.000612 \\
(0.295)\end{array}$ & $\begin{array}{l}0.00154 \\
(0.295)\end{array}$ & $\begin{array}{l}0.00713 \\
(0.295)\end{array}$ \\
\hline Wageworker & $\begin{array}{l}-0.164 * * \\
(0.0699)\end{array}$ & $\begin{array}{l}-0.162 * * \\
(0.0699)\end{array}$ & $\begin{array}{l}-0.163 * * \\
(0.0700)\end{array}$ & $\begin{array}{l}-0.161 * * \\
(0.0699)\end{array}$ \\
\hline Family & $\begin{array}{l}0.0716 \\
(0.118)\end{array}$ & $\begin{array}{l}0.0693 \\
(0.118)\end{array}$ & $\begin{array}{l}0.0650 \\
(0.118)\end{array}$ & $\begin{array}{l}0.0611 \\
(0.118)\end{array}$ \\
\hline Illness2 & $\begin{array}{l}-0.0237 \\
(0.0647)\end{array}$ & $\begin{array}{l}-0.0232 \\
(0.0648)\end{array}$ & $\begin{array}{l}-0.0242 \\
(0.0648)\end{array}$ & $\begin{array}{l}-0.0228 \\
(0.0648)\end{array}$ \\
\hline Condition2 & $\begin{array}{l}-0.121 \\
(0.0801)\end{array}$ & $\begin{array}{l}-0.121 \\
(0.0801)\end{array}$ & $\begin{array}{l}-0.121 \\
(0.0802)\end{array}$ & $\begin{array}{l}-0.123 \\
(0.0802)\end{array}$ \\
\hline Community 1 & $\begin{array}{l}0.0475 \\
(0.0576)\end{array}$ & $\begin{array}{l}0.0492 \\
(0.0576)\end{array}$ & $\begin{array}{l}0.0507 \\
(0.0576)\end{array}$ & $\begin{array}{l}0.0511 \\
(0.0576)\end{array}$ \\
\hline Religion & $\begin{array}{l}-0.254 \\
(0.256)\end{array}$ & $\begin{array}{l}-0.255 \\
(0.256)\end{array}$ & $\begin{array}{l}-0.257 \\
(0.256)\end{array}$ & $\begin{array}{l}-0.258 \\
(0.256)\end{array}$ \\
\hline Personality 1 & $\begin{array}{l}0.0974 * * * \\
(0.0311)\end{array}$ & $\begin{array}{l}0.0974 * * * \\
(0.0312)\end{array}$ & $\begin{array}{l}0.0982^{* * * *} \\
(0.0312)\end{array}$ & $\begin{array}{l}0.0990 * * * \\
(0.0312)\end{array}$ \\
\hline Personality2 & $\begin{array}{l}-0.0369^{*} \\
(0.0220)\end{array}$ & $\begin{array}{l}-0.0368^{*} \\
(0.0220)\end{array}$ & $\begin{array}{l}-0.0369^{*} \\
(0.0220)\end{array}$ & $\begin{array}{l}-0.0369^{*} \\
(0.0220)\end{array}$ \\
\hline Personality 3 & $\begin{array}{l}-0.0506^{*} \\
(0.0285)\end{array}$ & $\begin{array}{l}-0.0500 * \\
(0.0285)\end{array}$ & $\begin{array}{l}-0.0501^{*} \\
(0.0285)\end{array}$ & $\begin{array}{l}-0.0499 * \\
(0.0285)\end{array}$ \\
\hline Personality 4 & $\begin{array}{l}0.0295 \\
(0.0285)\end{array}$ & $\begin{array}{l}0.0295 \\
(0.0285)\end{array}$ & $\begin{array}{l}0.0303 \\
(0.0285)\end{array}$ & $\begin{array}{l}0.0301 \\
(0.0285)\end{array}$ \\
\hline Risk & $\begin{array}{l}0.0632 * * * \\
(0.0112)\end{array}$ & $\begin{array}{l}0.0632 * * * \\
(0.0112)\end{array}$ & $\begin{array}{l}0.0633 * * * \\
(0.0112)\end{array}$ & $\begin{array}{l}0.0632 * * * \\
(0.0112)\end{array}$ \\
\hline Circumstances & $\begin{array}{l}0.487 * * * \\
(0.0177)\end{array}$ & $\begin{array}{l}0.487 * * * \\
(0.0177)\end{array}$ & $\begin{array}{l}0.487 * * * \\
(0.0177)\end{array}$ & $\begin{array}{l}0.488 * * * \\
(0.0177)\end{array}$ \\
\hline Oblast1 & $\begin{array}{l}0.824 * * * \\
(0.171)\end{array}$ & $\begin{array}{l}0.826 * * * \\
(0.171)\end{array}$ & $\begin{array}{l}0.826 * * * \\
(0.171)\end{array}$ & $\begin{array}{l}0.834 * * * \\
(0.171)\end{array}$ \\
\hline Oblast2 & $\begin{array}{l}0.371 * * \\
(0.180)\end{array}$ & $\begin{array}{l}0.374 * * \\
(0.180)\end{array}$ & $\begin{array}{l}0.378^{* *} \\
(0.181)\end{array}$ & $\begin{array}{l}0.383 * * \\
(0.180)\end{array}$ \\
\hline Oblast3 & $-0.419 * *$ & $-0.419^{* *}$ & $-0.420^{* *}$ & $-0.417 * *$ \\
\hline
\end{tabular}


Table 15 (continued)

\begin{tabular}{|c|c|c|c|c|}
\hline \multirow[t]{3}{*}{ Variables } & (1) & (2) & (3) & (4) \\
\hline & Age-index1 & Age-index2 & Age-index3 & Age-index 4 \\
\hline & $(0.200)$ & $(0.200)$ & $(0.200)$ & $(0.200)$ \\
\hline \multirow[t]{2}{*}{ Oblast 4} & $1.117 * * *$ & $1.119 * * *$ & $1.122 * * *$ & $1.128 * * *$ \\
\hline & $(0.177)$ & $(0.177)$ & $(0.177)$ & $(0.177)$ \\
\hline \multirow[t]{2}{*}{ Oblast5 } & 0.289 & 0.292 & 0.291 & $0.302 *$ \\
\hline & $(0.180)$ & $(0.180)$ & $(0.180)$ & $(0.180)$ \\
\hline \multirow[t]{2}{*}{ Oblast6 } & $0.834 * * *$ & $0.838 * * *$ & $0.846^{* * * *}$ & $0.855 * * *$ \\
\hline & $(0.191)$ & $(0.191)$ & $(0.191)$ & $(0.190)$ \\
\hline \multirow[t]{2}{*}{ Oblast7 } & $0.710 * * *$ & $0.712 * * *$ & $0.712 * * *$ & $0.720 * * *$ \\
\hline & $(0.169)$ & $(0.169)$ & $(0.169)$ & $(0.169)$ \\
\hline \multirow[t]{2}{*}{ Oblast8 } & $0.434 * * *$ & $0.437 * * *$ & $0.441 * * *$ & $0.446 * * *$ \\
\hline & $(0.153)$ & $(0.153)$ & $(0.153)$ & $(0.153)$ \\
\hline \multirow[t]{2}{*}{ Constant } & $2.777 * * *$ & $2.803 * * *$ & $2.861 * * *$ & $2.881 * * *$ \\
\hline & $(0.527)$ & $(0.535)$ & $(0.543)$ & $(0.540)$ \\
\hline Observations & 2460 & 2460 & 2460 & 2460 \\
\hline R-squared & 0.358 & 0.357 & 0.357 & 0.357 \\
\hline
\end{tabular}

Standard errors in parentheses

$* * * p<0.01 ; * * p<0.05 ; * p<0.1$ 
Table 16 Full results from ordered probit analyses of age-weighted wages and hours worked sub-indices

\begin{tabular}{|c|c|c|c|c|}
\hline \multirow[t]{2}{*}{ Variables } & (1) & (2) & (3) & (4) \\
\hline & Awage-hours1 & Awage-hours2 & Awage-hours 3 & Awage-hours4 \\
\hline \multirow[t]{2}{*}{ Age-wage-hours } & 0.000673 & 0.000592 & 0.000574 & 0.000521 \\
\hline & $(0.000959)$ & $(0.000933)$ & $(0.000961)$ & $(0.00108)$ \\
\hline \multirow[t]{2}{*}{ Age } & $-0.0269 *$ & $-0.0273^{*}$ & $-0.0274^{*}$ & $-0.0276^{*}$ \\
\hline & $(0.0146)$ & $(0.0145)$ & $(0.0145)$ & $(0.0147)$ \\
\hline \multirow[t]{2}{*}{ Age2 } & 0.0293 & $0.0297 *$ & $0.0297 *$ & $0.0299 *$ \\
\hline & $(0.0180)$ & $(0.0179)$ & $(0.0179)$ & $(0.0180)$ \\
\hline \multirow[t]{2}{*}{ Gender } & -0.0320 & -0.0317 & -0.0315 & -0.0305 \\
\hline & $(0.0474)$ & $(0.0474)$ & $(0.0474)$ & $(0.0474)$ \\
\hline \multirow[t]{2}{*}{ Ethnicity } & 0.0425 & 0.0424 & 0.0423 & 0.0422 \\
\hline & $(0.0510)$ & $(0.0510)$ & $(0.0510)$ & $(0.0510)$ \\
\hline \multirow[t]{2}{*}{ Urban } & -0.0619 & -0.0616 & -0.0615 & -0.0606 \\
\hline & $(0.0656)$ & $(0.0656)$ & $(0.0657)$ & $(0.0656)$ \\
\hline \multirow[t]{2}{*}{ Education } & $0.0412 * *$ & $0.0414 * *$ & $0.0414 * *$ & $0.0416 * *$ \\
\hline & $(0.0175)$ & $(0.0175)$ & $(0.0175)$ & $(0.0175)$ \\
\hline \multirow[t]{2}{*}{ Employer } & 0.0465 & 0.0471 & 0.0474 & 0.0488 \\
\hline & $(0.222)$ & $(0.222)$ & $(0.222)$ & $(0.222)$ \\
\hline \multirow[t]{2}{*}{ Wageworker } & $-0.113^{* *}$ & $-0.113 * *$ & $-0.113^{* *}$ & $-0.113^{* *}$ \\
\hline & $(0.0516)$ & $(0.0516)$ & $(0.0516)$ & $(0.0516)$ \\
\hline \multirow[t]{2}{*}{ Family } & 0.0135 & 0.0128 & 0.0123 & 0.0105 \\
\hline & $(0.0874)$ & $(0.0875)$ & $(0.0875)$ & $(0.0874)$ \\
\hline \multirow[t]{2}{*}{ Illness2 } & -0.0281 & -0.0280 & -0.0280 & -0.0278 \\
\hline & $(0.0479)$ & $(0.0479)$ & $(0.0479)$ & $(0.0479)$ \\
\hline \multirow[t]{2}{*}{ Condition 2} & -0.0863 & -0.0863 & -0.0864 & -0.0868 \\
\hline & $(0.0591)$ & $(0.0591)$ & $(0.0591)$ & $(0.0591)$ \\
\hline \multirow[t]{2}{*}{ Community1 } & 0.0444 & 0.0446 & 0.0447 & 0.0446 \\
\hline & $(0.0426)$ & $(0.0426)$ & $(0.0426)$ & $(0.0426)$ \\
\hline \multirow[t]{2}{*}{ Religion } & -0.183 & -0.183 & -0.183 & -0.184 \\
\hline & $(0.190)$ & $(0.190)$ & $(0.190)$ & $(0.190)$ \\
\hline \multirow[t]{2}{*}{ Personality 1} & $0.0774 * * *$ & $0.0775 * * *$ & $0.0776 * * *$ & $0.0777 * * *$ \\
\hline & $(0.0230)$ & $(0.0230)$ & $(0.0230)$ & $(0.0230)$ \\
\hline \multirow[t]{2}{*}{ Personality2 } & $-0.0288^{*}$ & $-0.0288^{*}$ & $-0.0288^{*}$ & $-0.0288^{*}$ \\
\hline & $(0.0163)$ & $(0.0163)$ & $(0.0163)$ & $(0.0163)$ \\
\hline \multirow[t]{2}{*}{ Personality 3} & -0.0326 & -0.0326 & -0.0325 & -0.0325 \\
\hline & $(0.0210)$ & $(0.0210)$ & $(0.0210)$ & $(0.0210)$ \\
\hline \multirow[t]{2}{*}{ Personality 4} & 0.0259 & 0.0260 & 0.0260 & 0.0261 \\
\hline & $(0.0211)$ & $(0.0211)$ & $(0.0211)$ & $(0.0211)$ \\
\hline \multirow[t]{2}{*}{ Risk } & $0.0486 * * *$ & $0.0486 * * *$ & $0.0487 * * *$ & $0.0487 * * *$ \\
\hline & $(0.00840)$ & $(0.00840)$ & $(0.00840)$ & $(0.00839)$ \\
\hline \multirow[t]{2}{*}{ Circumstances } & $0.362 * * *$ & $0.362 * * *$ & $0.362 * * *$ & $0.362 * * *$ \\
\hline & $(0.0141)$ & $(0.0141)$ & $(0.0141)$ & $(0.0141)$ \\
\hline \multirow[t]{2}{*}{ Oblast1 } & $0.603 * * *$ & $0.604 * * *$ & $0.604 * * *$ & $0.603 * * *$ \\
\hline & $(0.126)$ & $(0.126)$ & $(0.126)$ & $(0.126)$ \\
\hline Oblast2 & $0.292 * *$ & $0.292 * *$ & $0.292 * *$ & $0.292 * *$ \\
\hline
\end{tabular}


Table 16 (continued)

\begin{tabular}{|c|c|c|c|c|}
\hline \multirow[t]{2}{*}{ Variables } & \multirow{2}{*}{$\begin{array}{l}\text { (1) } \\
\text { Awage-hours1 }\end{array}$} & \multirow{2}{*}{$\begin{array}{l}\text { (2) } \\
\text { Awage-hours2 }\end{array}$} & \multirow{2}{*}{$\begin{array}{l}\text { (3) } \\
\text { Awage-hours3 }\end{array}$} & \multirow{2}{*}{$\begin{array}{l}\text { (4) } \\
\text { Awage-hours4 }\end{array}$} \\
\hline & & & & \\
\hline & $(0.132)$ & $(0.132)$ & $(0.132)$ & $(0.132)$ \\
\hline \multirow[t]{2}{*}{ Oblast3 } & $-0.304 * *$ & $-0.304 * *$ & $-0.304 * *$ & $-0.302 * *$ \\
\hline & $(0.147)$ & $(0.147)$ & $(0.147)$ & $(0.147)$ \\
\hline \multirow[t]{2}{*}{ Oblast4 } & $0.880 * * *$ & $0.880 * * *$ & $0.881 * * *$ & $0.881 * * *$ \\
\hline & $(0.131)$ & $(0.131)$ & $(0.131)$ & $(0.131)$ \\
\hline \multirow[t]{2}{*}{ Oblast5 } & 0.207 & 0.208 & 0.208 & 0.209 \\
\hline & $(0.132)$ & $(0.132)$ & $(0.132)$ & $(0.132)$ \\
\hline \multirow[t]{2}{*}{ Oblast6 } & $0.630^{* * *}$ & $0.631 * * *$ & $0.631 * * *$ & $0.632 * * *$ \\
\hline & $(0.140)$ & $(0.140)$ & $(0.140)$ & $(0.140)$ \\
\hline \multirow[t]{2}{*}{ Oblast7 } & $0.525 * * *$ & $0.526 * * *$ & $0.526 * * *$ & $0.528 * * *$ \\
\hline & $(0.124)$ & $(0.124)$ & $(0.124)$ & $(0.124)$ \\
\hline \multirow[t]{2}{*}{ Oblast8 } & $0.351^{* * *}$ & $0.352 * * *$ & $0.352 * * *$ & $0.353 * * *$ \\
\hline & $(0.112)$ & $(0.112)$ & $(0.112)$ & $(0.112)$ \\
\hline \multirow[t]{2}{*}{ Constant cut 1} & $-1.549 * * *$ & $-1.561 * * *$ & $-1.563 * * *$ & $-1.568^{* * *}$ \\
\hline & $(0.477)$ & $(0.476)$ & $(0.477)$ & $(0.482)$ \\
\hline \multirow[t]{2}{*}{ Constant cut 2} & $-0.830^{* *}$ & $-0.842^{* *}$ & $-0.844^{* *}$ & $-0.848^{* *}$ \\
\hline & $(0.376)$ & $(0.374)$ & $(0.375)$ & $(0.382)$ \\
\hline \multirow[t]{2}{*}{ Constant cut 3} & -0.598 & $-0.610^{*}$ & $-0.612 *$ & $-0.617^{*}$ \\
\hline & $(0.366)$ & $(0.364)$ & $(0.365)$ & $(0.372)$ \\
\hline \multirow[t]{2}{*}{ Constant cut 4} & 0.177 & 0.164 & 0.162 & 0.158 \\
\hline & $(0.354)$ & $(0.352)$ & $(0.353)$ & $(0.360)$ \\
\hline \multirow[t]{2}{*}{ Constant cut 5} & $0.750 * *$ & $0.737 * *$ & $0.735^{* *}$ & $0.731 * *$ \\
\hline & $(0.353)$ & $(0.351)$ & $(0.352)$ & $(0.359)$ \\
\hline \multirow[t]{2}{*}{ Constant cut 6} & $1.592 * * *$ & $1.580 * * *$ & $1.578 * * *$ & $1.573 * * *$ \\
\hline & $(0.353)$ & $(0.351)$ & $(0.352)$ & $(0.359)$ \\
\hline \multirow[t]{2}{*}{ Constant cut7 } & $2.285^{* * *}$ & $2.272 * * *$ & $2.270 * * *$ & $2.266 * * *$ \\
\hline & $(0.354)$ & $(0.351)$ & $(0.353)$ & $(0.360)$ \\
\hline \multirow[t]{2}{*}{ Constant cut 8} & $3.007 * * *$ & $2.995 * * *$ & $2.993 * * *$ & $2.988 * * *$ \\
\hline & $(0.355)$ & $(0.352)$ & $(0.354)$ & $(0.361)$ \\
\hline \multirow[t]{2}{*}{ Constant cut 9} & $3.767 * * *$ & $3.754 * * *$ & $3.752 * * *$ & $3.748 * * *$ \\
\hline & $(0.356)$ & $(0.354)$ & $(0.355)$ & $(0.362)$ \\
\hline \multirow[t]{2}{*}{ Constant cut 10} & $4.259 * * *$ & $4.247 * * *$ & $4.245^{* * *}$ & $4.240 * * *$ \\
\hline & $(0.358)$ & $(0.355)$ & $(0.357)$ & $(0.364)$ \\
\hline Observations & 2460 & 2460 & 2460 & 2460 \\
\hline
\end{tabular}

Standard errors in parentheses

$* * * p<0.01 ; * * p<0.05 ; * p<0.1$ 
Table 17 Full results from ordered probit analyses of age-weighted full indices

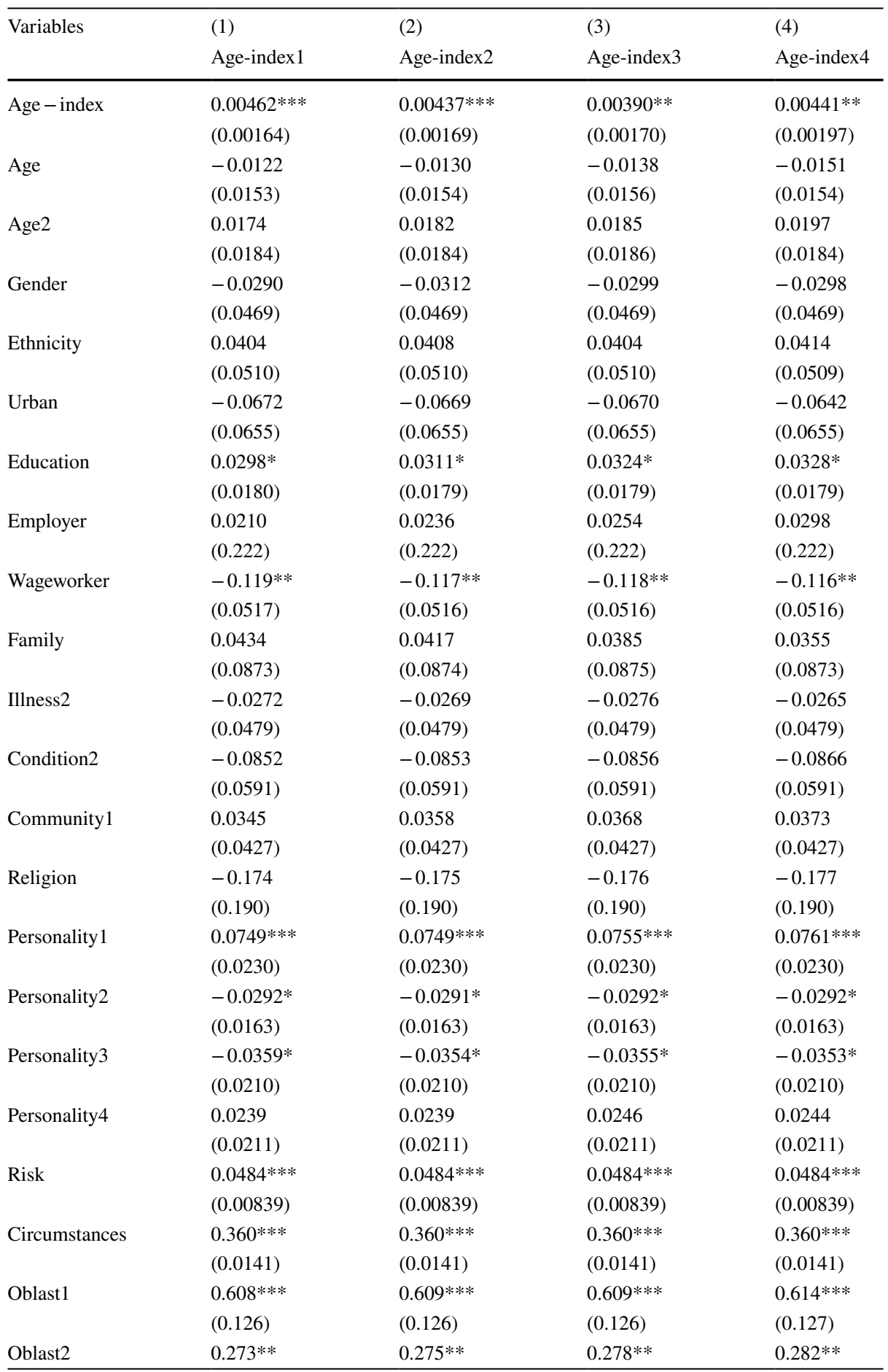


Table 17 (continued)

\begin{tabular}{|c|c|c|c|c|}
\hline Variables & $\begin{array}{l}\text { (1) } \\
\text { Age-index1 }\end{array}$ & $\begin{array}{l}\text { (2) } \\
\text { Age-index2 }\end{array}$ & $\begin{array}{l}\text { (3) } \\
\text { Age-index3 }\end{array}$ & $\begin{array}{l}\text { (4) } \\
\text { Age-index4 }\end{array}$ \\
\hline & $(0.132)$ & $(0.132)$ & $(0.132)$ & $(0.132)$ \\
\hline Oblast3 & $\begin{array}{l}-0.309^{* *} \\
(0.147)\end{array}$ & $\begin{array}{l}-0.309^{* *} \\
(0.147)\end{array}$ & $\begin{array}{l}-0.310^{* *} \\
(0.147)\end{array}$ & $\begin{array}{l}-0.308^{* *} \\
(0.147)\end{array}$ \\
\hline Oblast4 & $\begin{array}{l}0.875 * * * \\
(0.131)\end{array}$ & $\begin{array}{l}0.876 * * * \\
(0.131)\end{array}$ & $\begin{array}{l}0.878 * * * \\
(0.131)\end{array}$ & $\begin{array}{l}0.882^{* * * *} \\
(0.131)\end{array}$ \\
\hline Oblast5 & $\begin{array}{l}0.197 \\
(0.132)\end{array}$ & $\begin{array}{l}0.200 \\
(0.132)\end{array}$ & $\begin{array}{l}0.199 \\
(0.132)\end{array}$ & $\begin{array}{l}0.207 \\
(0.132)\end{array}$ \\
\hline Oblast6 & $\begin{array}{l}0.602 * * * \\
(0.140)\end{array}$ & $\begin{array}{l}0.605^{* * * *} \\
(0.140)\end{array}$ & $\begin{array}{l}0.610 * * * \\
(0.140)\end{array}$ & $\begin{array}{l}0.618 * * * \\
(0.140)\end{array}$ \\
\hline Oblast7 & $\begin{array}{l}0.521 * * * \\
(0.124)\end{array}$ & $\begin{array}{l}0.522 * * * \\
(0.124)\end{array}$ & $\begin{array}{l}0.522 * * * \\
(0.124)\end{array}$ & $\begin{array}{l}0.528 * * * \\
(0.124)\end{array}$ \\
\hline Oblast8 & $\begin{array}{l}0.334 * * * \\
(0.112)\end{array}$ & $\begin{array}{l}0.336^{* * *} \\
(0.112)\end{array}$ & $\begin{array}{l}0.339 * * * \\
(0.112)\end{array}$ & $\begin{array}{l}0.343 * * * \\
(0.112)\end{array}$ \\
\hline Constant cut 1 & $\begin{array}{l}-1.042^{* *} \\
(0.505)\end{array}$ & $\begin{array}{l}-1.061^{* *} \\
(0.510)\end{array}$ & $\begin{array}{l}-1.104^{* *} \\
(0.515)\end{array}$ & $\begin{array}{l}-1.128^{* *} \\
(0.512)\end{array}$ \\
\hline Constant cut 2 & $\begin{array}{l}-0.329 \\
(0.413)\end{array}$ & $\begin{array}{l}-0.348 \\
(0.418)\end{array}$ & $\begin{array}{l}-0.390 \\
(0.424)\end{array}$ & $\begin{array}{l}-0.414 \\
(0.421)\end{array}$ \\
\hline Constant cut 3 & $\begin{array}{l}-0.0971 \\
(0.403)\end{array}$ & $\begin{array}{l}-0.116 \\
(0.409)\end{array}$ & $\begin{array}{l}-0.159 \\
(0.415)\end{array}$ & $\begin{array}{l}-0.182 \\
(0.412)\end{array}$ \\
\hline Constant cut 4 & $\begin{array}{l}0.679 * \\
(0.393)\end{array}$ & $\begin{array}{l}0.659^{*} \\
(0.398)\end{array}$ & $\begin{array}{l}0.617 \\
(0.404)\end{array}$ & $\begin{array}{l}0.595 \\
(0.401)\end{array}$ \\
\hline Constant cut5 & $\begin{array}{l}1.252 * * * \\
(0.392)\end{array}$ & $\begin{array}{l}1.233 * * * \\
(0.397)\end{array}$ & $\begin{array}{l}1.190 * * * \\
(0.403)\end{array}$ & $\begin{array}{l}1.168^{* * * *} \\
(0.400)\end{array}$ \\
\hline Constant cut6 & $\begin{array}{l}2.096 * * * \\
(0.392)\end{array}$ & $\begin{array}{l}2.077 * * * \\
(0.397)\end{array}$ & $\begin{array}{l}2.033 * * * \\
(0.403)\end{array}$ & $\begin{array}{l}2.011^{* * *} \\
(0.401)\end{array}$ \\
\hline Constant cut 7 & $\begin{array}{l}2.790 * * * \\
(0.393)\end{array}$ & $\begin{array}{l}2.770^{* * * *} \\
(0.398)\end{array}$ & $\begin{array}{l}2.727 * * * \\
(0.404)\end{array}$ & $\begin{array}{l}2.704 * * * \\
(0.401)\end{array}$ \\
\hline Constant cut 8 & $\begin{array}{l}3.514 * * * \\
(0.394)\end{array}$ & $\begin{array}{l}3.494 * * * \\
(0.399)\end{array}$ & $\begin{array}{l}3.450 * * * \\
(0.405)\end{array}$ & $\begin{array}{l}3.428 * * * \\
(0.402)\end{array}$ \\
\hline Constant cut 9 & $\begin{array}{l}4.275^{* * *} \\
(0.395)\end{array}$ & $\begin{array}{l}4.254 * * * \\
(0.401)\end{array}$ & $\begin{array}{l}4.210 * * * \\
(0.407)\end{array}$ & $\begin{array}{l}4.188^{* * * *} \\
(0.404)\end{array}$ \\
\hline Constant cut 10 & $\begin{array}{l}4.768 * * * \\
(0.397)\end{array}$ & $\begin{array}{l}4.747 * * * \\
(0.402)\end{array}$ & $\begin{array}{l}4.703 * * * \\
(0.408)\end{array}$ & $\begin{array}{l}4.681 * * * \\
(0.405)\end{array}$ \\
\hline Observations & 2460 & 2460 & 2460 & 2460 \\
\hline
\end{tabular}

Standard errors in parentheses

*** $p<0.01 ; * * p<0.05 ; * p<0.1$ 
Table 18 Main OLS results for full indices using linear hours worked

Table 19 Main OLS results for truncated indices using linear hours worked

\begin{tabular}{lllll}
\hline Variables & $(1)$ & $(2)$ & $(3)$ & $(4)$ \\
& Index 1 & Index 2 & Index 3 & Index 4 \\
\hline Index1b & $\begin{array}{l}0.00275^{* *} \\
(0.00134)\end{array}$ & & & \\
& & $0.00276^{* *}$ & & \\
Index2b & & $(0.00134)$ & & \\
& & & $0.00268^{* *}$ & \\
Index3b & & & $(0.00135)$ & \\
& & & & $0.00308^{*}$ \\
Index4b & & & & $(0.00164)$ \\
& & & & \\
Constant & $6.700^{* * *}$ & $6.702^{* * *}$ & $6.694 * * *$ & $6.676^{* * *}$ \\
& $(0.511)$ & $(0.511)$ & $(0.511)$ & $(0.513)$ \\
Observations & 2467 & 2467 & 2467 & 2467 \\
R-squared & 0.102 & 0.102 & 0.102 & 0.102 \\
\hline
\end{tabular}

Standard errors in parentheses

$* * * p<0.01 ; * * p<0.05 ; * p<0.1$

\begin{tabular}{lllll}
\hline Variables & $(1)$ & $(2)$ & $(3)$ & $(4)$ \\
& Index 1 & Index 2 & Index 3 & Index 4 \\
\hline Wage-hours1b & -0.000681 & & & \\
& $(0.000429)$ & & & \\
Wage-hours2b & & -0.000679 & & \\
& & $(0.000427)$ & & \\
Wage-hours3b & & & $(0.000446)$ & \\
& & & & \\
Wage-hours4b & & & & \\
& & & & \\
Constant & $3.615 * * *$ & $3.613 * * *$ & $3.614 * * *$ & $3.572 * * * 00281$ \\
& $(0.448)$ & $(0.448)$ & $(0.448)$ & $(0.448)$ \\
Observations & 2460 & 2460 & 2460 & 2460 \\
R-squared & 0.356 & 0.356 & 0.356 & 0.356 \\
\hline
\end{tabular}

Standard errors in parentheses

$* * * p<0.01 ; * * p<0.05 ; * p<0.1$ 
Table 20 Results from Index 5

\begin{tabular}{|c|c|c|c|c|c|}
\hline Variables & $\begin{array}{l}\text { (1) } \\
\text { Index } 5\end{array}$ & $\begin{array}{l}(2) \\
\text { Index } 5\end{array}$ & $\begin{array}{l}(3) \\
\text { Index } 5\end{array}$ & $\begin{array}{l}(4) \\
\text { Index } 5\end{array}$ & $\begin{array}{l}(5) \\
\text { Index } 5\end{array}$ \\
\hline Index 5 & $\begin{array}{l}0.00879 * * * \\
(0.00229)\end{array}$ & $\begin{array}{l}0.00854 * * * \\
(0.00229)\end{array}$ & $\begin{array}{l}0.00791 * * * \\
(0.00230)\end{array}$ & $\begin{array}{l}0.00834 * * * \\
(0.00227)\end{array}$ & $\begin{array}{l}0.00843 * * * \\
(0.00229)\end{array}$ \\
\hline Age & $\begin{array}{l}-0.0548^{* *} \\
(0.0230)\end{array}$ & $\begin{array}{l}-0.0547 * * \\
(0.0230)\end{array}$ & $\begin{array}{l}-0.0552 * * \\
(0.0229)\end{array}$ & $\begin{array}{l}-0.0465^{* *} \\
(0.0226)\end{array}$ & $\begin{array}{l}-0.0437 * \\
(0.0223)\end{array}$ \\
\hline Age2 & $\begin{array}{l}0.0551 * \\
(0.0290)\end{array}$ & $\begin{array}{l}0.0589 * * \\
(0.0290)\end{array}$ & $\begin{array}{l}0.0585^{* *} \\
(0.0289)\end{array}$ & $\begin{array}{l}0.0485 * \\
(0.0285)\end{array}$ & $\begin{array}{l}0.0432 \\
(0.0282)\end{array}$ \\
\hline Gender & $\begin{array}{l}0.0944 \\
(0.0746)\end{array}$ & $\begin{array}{l}0.0541 \\
(0.0757)\end{array}$ & $\begin{array}{l}0.0623 \\
(0.0759)\end{array}$ & $\begin{array}{l}0.0500 \\
(0.0749)\end{array}$ & $\begin{array}{l}0.0322 \\
(0.0741)\end{array}$ \\
\hline Ethnicity & $\begin{array}{l}0.0880 \\
(0.0784)\end{array}$ & $\begin{array}{l}0.110 \\
(0.0786)\end{array}$ & $\begin{array}{l}0.0690 \\
(0.0792)\end{array}$ & $\begin{array}{l}0.0650 \\
(0.0783)\end{array}$ & $\begin{array}{l}0.00167 \\
(0.0812)\end{array}$ \\
\hline Urban & $\begin{array}{l}-0.263 * * * \\
(0.0762)\end{array}$ & $\begin{array}{l}-0.236 * * * \\
(0.0766)\end{array}$ & $\begin{array}{l}-0.194 * * \\
(0.0774)\end{array}$ & $\begin{array}{l}-0.193 * * \\
(0.0771)\end{array}$ & $\begin{array}{l}-0.324 * * * \\
(0.104)\end{array}$ \\
\hline Education & $\begin{array}{l}0.139 * * * \\
(0.0284)\end{array}$ & $\begin{array}{l}0.136 * * * \\
(0.0284)\end{array}$ & $\begin{array}{l}0.133 * * * \\
(0.0284)\end{array}$ & $\begin{array}{l}0.100 * * * \\
(0.0283)\end{array}$ & $\begin{array}{l}0.0965 * * * \\
(0.0283)\end{array}$ \\
\hline Employer & $\begin{array}{l}0.271 \\
(0.358)\end{array}$ & $\begin{array}{l}0.238 \\
(0.357)\end{array}$ & $\begin{array}{l}0.204 \\
(0.357)\end{array}$ & $\begin{array}{l}0.0570 \\
(0.351)\end{array}$ & $\begin{array}{l}0.182 \\
(0.348)\end{array}$ \\
\hline Wageworker & $\begin{array}{l}-0.235^{* * * *} \\
(0.0822)\end{array}$ & $\begin{array}{l}-0.247 * * * \\
(0.0823)\end{array}$ & $\begin{array}{l}-0.258^{* * * *} \\
(0.0822)\end{array}$ & $\begin{array}{l}-0.261 * * * \\
(0.0809)\end{array}$ & $\begin{array}{l}-0.225^{* * *} \\
(0.0822)\end{array}$ \\
\hline Family & $\begin{array}{l}0.299 * * \\
(0.140)\end{array}$ & $\begin{array}{l}0.299 * * \\
(0.140)\end{array}$ & $\begin{array}{l}0.306 * * \\
(0.140)\end{array}$ & $\begin{array}{l}0.330^{* * *} \\
(0.138)\end{array}$ & $\begin{array}{l}0.148 \\
(0.138)\end{array}$ \\
\hline Illness2 & & $\begin{array}{l}-0.0665 \\
(0.0759)\end{array}$ & $\begin{array}{l}-0.0570 \\
(0.0759)\end{array}$ & $\begin{array}{l}-0.0665 \\
(0.0749)\end{array}$ & $\begin{array}{l}-0.136^{*} \\
(0.0753)\end{array}$ \\
\hline Condition 2 & & $\begin{array}{l}-0.329 * * * \\
(0.0959)\end{array}$ & $\begin{array}{l}-0.347 * * * \\
(0.0960)\end{array}$ & $\begin{array}{l}-0.297 * * * \\
(0.0949)\end{array}$ & $\begin{array}{l}-0.235^{* * *} \\
(0.0942)\end{array}$ \\
\hline Community 1 & & & $\begin{array}{l}0.210 * * * \\
(0.0659)\end{array}$ & $\begin{array}{l}0.201 * * * \\
(0.0651)\end{array}$ & $\begin{array}{l}0.235^{* * * *} \\
(0.0676)\end{array}$ \\
\hline Religion & & & $\begin{array}{l}-0.0781 \\
(0.309)\end{array}$ & $\begin{array}{l}-0.193 \\
(0.305)\end{array}$ & $\begin{array}{l}-0.296 \\
(0.302)\end{array}$ \\
\hline Personality1 & & & & $\begin{array}{l}0.235 * * * \\
(0.0359)\end{array}$ & $\begin{array}{l}0.188 * * * \\
(0.0365)\end{array}$ \\
\hline Personality 2 & & & & $\begin{array}{l}-0.0358 \\
(0.0260)\end{array}$ & $\begin{array}{l}-0.0279 \\
(0.0258)\end{array}$ \\
\hline Personality 3 & & & & $\begin{array}{l}-0.160 * * * \\
(0.0336)\end{array}$ & $\begin{array}{l}-0.131 * * * \\
(0.0334)\end{array}$ \\
\hline Personality4 & & & & $\begin{array}{l}0.0217 \\
(0.0338)\end{array}$ & $\begin{array}{l}0.0471 \\
(0.0335)\end{array}$ \\
\hline Region 1 & & & & & $\begin{array}{l}0.548 * * * \\
(0.200)\end{array}$ \\
\hline Region2 & & & & & $\begin{array}{l}-0.183 \\
(0.209)\end{array}$ \\
\hline Region3 & & & & & $\begin{array}{l}-0.396^{*} \\
(0.233)\end{array}$ \\
\hline Region4 & & & & & $0.938 * * *$ \\
\hline
\end{tabular}


Table 20 (continued)

\begin{tabular}{|c|c|c|c|c|c|}
\hline \multirow[t]{2}{*}{ Variables } & (1) & (2) & (3) & (4) & (5) \\
\hline & Index 5 & Index 5 & Index 5 & Index 5 & Index 5 \\
\hline & & & & & $(0.205)$ \\
\hline \multirow[t]{2}{*}{ Region5 } & & & & & 0.0764 \\
\hline & & & & & $(0.210)$ \\
\hline \multirow[t]{2}{*}{ Region6 } & & & & & 0.222 \\
\hline & & & & & $(0.223)$ \\
\hline \multirow[t]{2}{*}{ Region7 } & & & & & 0.125 \\
\hline & & & & & $(0.195)$ \\
\hline \multirow[t]{2}{*}{ Region8 } & & & & & $0.376^{* *}$ \\
\hline & & & & & $(0.177)$ \\
\hline \multirow[t]{2}{*}{ Constant } & $7.256^{* * * *}$ & $7.321 * * *$ & $7.367 * * *$ & $6.871 * * *$ & $6.763 * * *$ \\
\hline & $(0.449)$ & $(0.450)$ & (0.449) & $(0.480)$ & $(0.508)$ \\
\hline Observations & 2484 & 2477 & 2470 & 2467 & 2467 \\
\hline R-squared & 0.032 & 0.039 & 0.042 & 0.075 & 0.106 \\
\hline
\end{tabular}

Standard errors in parentheses

$* * * p<0.01 ; * * p<0.05 ; * p<0.1$ 
Table 21 OLS analysis on heterogeneous effects for Index 1

\begin{tabular}{|c|c|c|c|c|}
\hline Variables & $\begin{array}{l}\text { (1) } \\
\text { Old }\end{array}$ & $\begin{array}{l}\text { (2) } \\
\text { Young }\end{array}$ & $\begin{array}{l}\text { (3) } \\
\text { Women }\end{array}$ & $\begin{array}{l}\text { (4) } \\
\text { Men }\end{array}$ \\
\hline Index 1 & $\begin{array}{l}0.0109^{* * *} \\
(0.00329)\end{array}$ & $\begin{array}{l}0.0155^{* * * *} \\
(0.00323)\end{array}$ & $\begin{array}{l}0.0139 * * * \\
(0.00377)\end{array}$ & $\begin{array}{l}0.0116 * * * \\
(0.00294)\end{array}$ \\
\hline Age & $\begin{array}{l}-0.118 \\
(0.130)\end{array}$ & $\begin{array}{l}-0.122 \\
(0.0919)\end{array}$ & $\begin{array}{l}-0.0686 \\
(0.0420)\end{array}$ & $\begin{array}{l}-0.0171 \\
(0.0264)\end{array}$ \\
\hline Age2 & $\begin{array}{l}0.120 \\
(0.132)\end{array}$ & $\begin{array}{l}0.189 \\
(0.158)\end{array}$ & $\begin{array}{l}0.0717 \\
(0.0541)\end{array}$ & $\begin{array}{l}0.0133 \\
(0.0329)\end{array}$ \\
\hline Gender & $\begin{array}{l}0.0272 \\
(0.110)\end{array}$ & $\begin{array}{l}0.0104 \\
(0.101)\end{array}$ & - & - \\
\hline Ethnicity & $\begin{array}{l}0.0702 \\
(0.119)\end{array}$ & $\begin{array}{l}-0.0464 \\
(0.111)\end{array}$ & $\begin{array}{l}0.125 \\
(0.135)\end{array}$ & $\begin{array}{l}-0.0973 \\
(0.101)\end{array}$ \\
\hline Urban & $\begin{array}{l}-0.477^{* * *} \\
(0.148)\end{array}$ & $\begin{array}{l}-0.0807 \\
(0.146)\end{array}$ & $\begin{array}{l}-0.267 \\
(0.168)\end{array}$ & $\begin{array}{l}-0.393 \text { *** } \\
(0.132)\end{array}$ \\
\hline Education & $\begin{array}{l}0.0703 \\
(0.0449)\end{array}$ & $\begin{array}{l}0.0532 \\
(0.0394)\end{array}$ & $\begin{array}{l}0.0269 \\
(0.0498)\end{array}$ & $\begin{array}{l}0.0857 * * \\
(0.0364)\end{array}$ \\
\hline Employer & $\begin{array}{l}0.189 \\
(0.403)\end{array}$ & $\begin{array}{l}-0.0166 \\
(0.743)\end{array}$ & $\begin{array}{l}0.685 \\
(0.779)\end{array}$ & $\begin{array}{l}-0.0136 \\
(0.386)\end{array}$ \\
\hline Wageworker & $\begin{array}{l}-0.225^{*} \\
(0.116)\end{array}$ & $\begin{array}{l}-0.321^{* * * *} \\
(0.117)\end{array}$ & $\begin{array}{l}-0.127 \\
(0.159)\end{array}$ & $\begin{array}{l}-0.327 * * * \\
(0.0957)\end{array}$ \\
\hline Family & $\begin{array}{l}-0.0611 \\
(0.214)\end{array}$ & $\begin{array}{l}0.381 * * \\
(0.182)\end{array}$ & $\begin{array}{l}-0.0959 \\
(0.214)\end{array}$ & $\begin{array}{l}0.642 * * * \\
(0.196)\end{array}$ \\
\hline Illness2 & $\begin{array}{l}-0.0792 \\
(0.115)\end{array}$ & $\begin{array}{l}-0.138 \\
(0.100)\end{array}$ & $\begin{array}{l}-0.280^{* *} \\
(0.127)\end{array}$ & $\begin{array}{l}-0.0901 \\
(0.0940)\end{array}$ \\
\hline Condition2 & $\begin{array}{l}-0.136 \\
(0.123)\end{array}$ & $\begin{array}{l}-0.407 * * * \\
(0.152)\end{array}$ & $\begin{array}{l}-0.253 * \\
(0.143)\end{array}$ & $\begin{array}{l}-0.150 \\
(0.126)\end{array}$ \\
\hline Community 1 & $\begin{array}{l}0.174 * \\
(0.0888)\end{array}$ & $\begin{array}{l}0.247 * * \\
(0.106)\end{array}$ & $\begin{array}{l}0.0466 \\
(0.100)\end{array}$ & $\begin{array}{l}0.371 * * * \\
(0.0927)\end{array}$ \\
\hline Religion & $\begin{array}{l}-0.679 \\
(0.443)\end{array}$ & $\begin{array}{l}0.0447 \\
(0.412)\end{array}$ & $\begin{array}{l}-0.739 \\
(0.575)\end{array}$ & $\begin{array}{l}-0.101 \\
(0.351)\end{array}$ \\
\hline Personality1 & $\begin{array}{l}0.259 * * * \\
(0.0532)\end{array}$ & $\begin{array}{l}0.110^{* *} \\
(0.0502)\end{array}$ & $\begin{array}{l}0.149 * * \\
(0.0608)\end{array}$ & $\begin{array}{l}0.202 * * * \\
(0.0455)\end{array}$ \\
\hline Personality2 & $\begin{array}{l}-0.0179 \\
(0.0379)\end{array}$ & $\begin{array}{l}-0.0406 \\
(0.0353)\end{array}$ & $\begin{array}{l}-0.0779 * \\
(0.0417)\end{array}$ & $\begin{array}{l}0.00749 \\
(0.0328)\end{array}$ \\
\hline Personality3 & $\begin{array}{l}-0.124 * * * \\
(0.0479)\end{array}$ & $\begin{array}{l}-0.137 * * * \\
(0.0467)\end{array}$ & $\begin{array}{l}-0.220 * * * \\
(0.0536)\end{array}$ & $\begin{array}{l}-0.0686 \\
(0.0425)\end{array}$ \\
\hline Personality4 & $\begin{array}{l}0.0394 \\
(0.0493)\end{array}$ & $\begin{array}{l}0.0555 \\
(0.0456)\end{array}$ & $\begin{array}{l}-0.0112 \\
(0.0549)\end{array}$ & $\begin{array}{l}0.0744 * \\
(0.0422)\end{array}$ \\
\hline Region1 & $\begin{array}{l}0.201 \\
(0.305)\end{array}$ & $\begin{array}{l}0.892 * * * \\
(0.267)\end{array}$ & $\begin{array}{l}0.980 * * * \\
(0.336)\end{array}$ & $\begin{array}{l}0.327 \\
(0.247)\end{array}$ \\
\hline Region2 & $\begin{array}{l}-0.629^{* *} \\
(0.319)\end{array}$ & $\begin{array}{l}0.250 \\
(0.280)\end{array}$ & $\begin{array}{l}0.0278 \\
(0.356)\end{array}$ & $\begin{array}{l}-0.363 \\
(0.258)\end{array}$ \\
\hline Region3 & $\begin{array}{l}-0.451 \\
(0.363)\end{array}$ & $\begin{array}{l}-0.398 \\
(0.303)\end{array}$ & $\begin{array}{l}-0.301 \\
(0.405)\end{array}$ & $\begin{array}{l}-0.485^{*} \\
(0.285)\end{array}$ \\
\hline Region4 & $\begin{array}{l}0.882 * * * \\
(0.322)\end{array}$ & $\begin{array}{l}0.942 * * * \\
(0.265)\end{array}$ & $\begin{array}{l}0.784 * * \\
(0.370)\end{array}$ & $\begin{array}{l}0.974 * * * \\
(0.246)\end{array}$ \\
\hline Region5 & -0.217 & 0.333 & 0.422 & -0.152 \\
\hline
\end{tabular}


Table 21 (continued)

\begin{tabular}{lllll}
\hline Variables & $(1)$ & $(2)$ & $(3)$ & $(4)$ \\
& Old & Young & Women & Men \\
\hline \multirow{2}{*}{ Region6 } & $(0.330)$ & $(0.272)$ & $(0.368)$ & $(0.255)$ \\
& 0.0416 & 0.283 & 0.577 & 0.0100 \\
Region7 & $(0.339)$ & $(0.294)$ & $(0.365)$ & $(0.280)$ \\
& -0.460 & $0.593 * *$ & 0.411 & -0.0837 \\
Region8 & $(0.309)$ & $(0.251)$ & $(0.332)$ & $(0.240)$ \\
& -0.113 & $0.648 * * *$ & $0.538^{*}$ & 0.259 \\
Constant & $(0.281)$ & $(0.226)$ & $(0.301)$ & $(0.218)$ \\
& $8.576 * * *$ & $7.693 * * *$ & $7.690 * * *$ & $6.024 * * *$ \\
Observations & 1202 & $(1.338)$ & $(0.881)$ & $(0.609)$ \\
R-squared & 0.138 & 0.113 & 0.125 & 0.130 \\
\hline
\end{tabular}

Standard errors in parentheses

$* * * p<0.01 ; * * p<0.05 ;{ }^{*} p<0.1$ 
Table 22 OLS and ordered probit on "objective" and "subjective" components of job quality index (equal weighting version)

\begin{tabular}{|c|c|c|c|c|}
\hline \multirow[t]{3}{*}{ Variables } & \multicolumn{2}{|l|}{ OLS } & \multicolumn{2}{|l|}{ Oprobit } \\
\hline & (1) & $(2)$ & (3) & (4) \\
\hline & obj & sub & obj & sub \\
\hline \multirow[t]{2}{*}{ obj } & $0.0122 * * *$ & $0.0191 * * *$ & $0.00751 * * *$ & $0.0121 * * *$ \\
\hline & $(0.00290)$ & $(0.00429)$ & $(0.00180)$ & $(0.00268)$ \\
\hline \multirow[t]{2}{*}{ Age } & $-0.0453^{* *}$ & -0.0323 & $-0.0288^{* *}$ & -0.0209 \\
\hline & $(0.0223)$ & $(0.0222)$ & $(0.0139)$ & $(0.0138)$ \\
\hline \multirow[t]{2}{*}{ Age2 } & 0.0453 & 0.0331 & $0.0291 *$ & 0.0217 \\
\hline & $(0.0282)$ & $(0.0281)$ & $(0.0175)$ & $(0.0175)$ \\
\hline \multirow[t]{2}{*}{ Gender } & 0.0146 & 0.0811 & 0.00695 & 0.0484 \\
\hline & $(0.0743)$ & $(0.0743)$ & $(0.0462)$ & $(0.0462)$ \\
\hline \multirow[t]{2}{*}{ Ethnicity } & 0.000264 & -0.0106 & 0.00211 & -0.00487 \\
\hline & $(0.0811)$ & $(0.0811)$ & $(0.0503)$ & $(0.0503)$ \\
\hline \multirow[t]{2}{*}{ Urban } & $-0.312 * * *$ & $-0.353 * * *$ & $-0.205^{* * *}$ & $-0.231 * * *$ \\
\hline & $(0.104)$ & $(0.104)$ & $(0.0645)$ & $(0.0647)$ \\
\hline \multirow[t]{2}{*}{ Education } & $0.0878 * * *$ & $0.0867 * * *$ & $0.0552 * * *$ & $0.0540 * * *$ \\
\hline & $(0.0286)$ & $(0.0286)$ & $(0.0178)$ & $(0.0178)$ \\
\hline \multirow[t]{2}{*}{ Employer } & 0.179 & 0.141 & 0.126 & 0.103 \\
\hline & $(0.348)$ & $(0.348)$ & $(0.219)$ & (0.219) \\
\hline \multirow[t]{2}{*}{ Wageworker } & $-0.239 * * *$ & $-0.257 * * *$ & $-0.147 * * *$ & $-0.158 * * *$ \\
\hline & $(0.0823)$ & $(0.0825)$ & $(0.0511)$ & $(0.0513)$ \\
\hline \multirow[t]{2}{*}{ Family } & 0.139 & 0.160 & 0.0832 & 0.0964 \\
\hline & $(0.138)$ & $(0.138)$ & $(0.0858)$ & $(0.0860)$ \\
\hline \multirow[t]{2}{*}{ Illness2 } & $-0.134 *$ & $-0.142 *$ & $-0.0922 * *$ & $-0.0960 * *$ \\
\hline & $(0.0753)$ & $(0.0752)$ & $(0.0469)$ & $(0.0469)$ \\
\hline \multirow[t]{2}{*}{ Condition2 } & $-0.232 * *$ & $-0.237 * *$ & $-0.143 * *$ & $-0.146^{* *}$ \\
\hline & $(0.0941)$ & $(0.0940)$ & $(0.0584)$ & $(0.0584)$ \\
\hline \multirow[t]{2}{*}{ Community1 } & $0.245^{* * *}$ & $0.225^{* * *} *$ & $0.155^{* * *}$ & $0.142 * * *$ \\
\hline & $(0.0672)$ & $(0.0676)$ & $(0.0421)$ & $(0.0423)$ \\
\hline \multirow[t]{2}{*}{ Religion } & -0.260 & -0.290 & -0.156 & -0.172 \\
\hline & $(0.302)$ & $(0.302)$ & $(0.188)$ & $(0.188)$ \\
\hline \multirow[t]{2}{*}{ Personality1 } & $0.185^{* * * *}$ & $0.192 * * *$ & $0.118^{* * * *}$ & $0.122 * * *$ \\
\hline & $(0.0365)$ & $(0.0364)$ & $(0.0227)$ & $(0.0227)$ \\
\hline \multirow[t]{2}{*}{ Personality 2} & -0.0310 & -0.0316 & -0.0206 & -0.0212 \\
\hline & $(0.0258)$ & $(0.0258)$ & $(0.0161)$ & $(0.0161)$ \\
\hline \multirow[t]{2}{*}{ Personality3 } & $-0.127 * * *$ & $-0.131 * * *$ & $-0.0780^{* * *}$ & $-0.0805^{* * *} *$ \\
\hline & $(0.0334)$ & $(0.0334)$ & $(0.0207)$ & $(0.0207)$ \\
\hline \multirow[t]{2}{*}{ Personality4 } & 0.0466 & 0.0533 & 0.0304 & $0.0346^{*}$ \\
\hline & $(0.0335)$ & $(0.0335)$ & $(0.0208)$ & $(0.0208)$ \\
\hline \multirow[t]{2}{*}{ Region1 } & $0.548^{* * *} *$ & $0.560 * * *$ & $0.348 * * *$ & $0.354 * * *$ \\
\hline & $(0.199)$ & $(0.199)$ & $(0.124)$ & $(0.124)$ \\
\hline \multirow[t]{2}{*}{ Region2 } & -0.143 & -0.205 & -0.0970 & -0.136 \\
\hline & $(0.209)$ & $(0.209)$ & $(0.129)$ & $(0.129)$ \\
\hline Region3 & $-0.401 *$ & $-0.435 *$ & $-0.252 *$ & $-0.273^{*}$ \\
\hline
\end{tabular}


Table 22 (continued)

\begin{tabular}{|c|c|c|c|c|}
\hline \multirow[t]{3}{*}{ Variables } & \multicolumn{2}{|l|}{ OLS } & \multicolumn{2}{|l|}{ Oprobit } \\
\hline & (1) & (2) & (3) & (4) \\
\hline & obj & sub & obj & sub \\
\hline & $(0.233)$ & $(0.233)$ & $(0.144)$ & $(0.144)$ \\
\hline \multirow[t]{2}{*}{ Region4 } & $0.948 * * *$ & $0.919 * * *$ & $0.626^{* * *}$ & $0.609 * * *$ \\
\hline & $(0.205)$ & $(0.205)$ & $(0.128)$ & $(0.128)$ \\
\hline \multirow[t]{2}{*}{ Region5 } & 0.0942 & 0.0156 & 0.0394 & -0.0102 \\
\hline & $(0.210)$ & $(0.210)$ & $(0.130)$ & $(0.130)$ \\
\hline \multirow[t]{2}{*}{ Region6 } & 0.254 & 0.260 & 0.140 & 0.142 \\
\hline & $(0.221)$ & $(0.221)$ & $(0.137)$ & $(0.137)$ \\
\hline \multirow[t]{2}{*}{ Region7 } & 0.123 & 0.102 & 0.0692 & 0.0563 \\
\hline & $(0.195)$ & $(0.195)$ & $(0.121)$ & $(0.121)$ \\
\hline \multirow[t]{4}{*}{ Region8 } & $0.376^{* *}$ & $0.371 * *$ & $0.241 * *$ & $0.238 * *$ \\
\hline & $(0.177)$ & $(0.177)$ & (0.109) & (0.109) \\
\hline & $6.602 * * *$ & $6.078 * * *$ & - & - \\
\hline & $(0.510)$ & $(0.523)$ & - & - \\
\hline \multirow[t]{2}{*}{ Constant cut 1} & & & $-3.215^{* * *}$ & $-2.856^{* * * *}$ \\
\hline & & & $(0.414)$ & $(0.423)$ \\
\hline \multirow[t]{2}{*}{ Constant cut 2} & & & $-2.648 * * *$ & $-2.298 * * *$ \\
\hline & & & $(0.338)$ & $(0.351)$ \\
\hline \multirow[t]{2}{*}{ Constant cut 3} & & & $-2.463 * * *$ & $-2.118 * * *$ \\
\hline & & & $(0.330)$ & $(0.343)$ \\
\hline \multirow[t]{2}{*}{ Constant cut 4} & & & $-1.840 * * *$ & $-1.503 * * *$ \\
\hline & & & $(0.320)$ & $(0.333)$ \\
\hline \multirow[t]{2}{*}{ Constant cut5 } & & & $-1.365 * * *$ & $-1.032 * * *$ \\
\hline & & & $(0.318)$ & $(0.331)$ \\
\hline \multirow[t]{2}{*}{ Constant cut 6} & & & $-0.656 * *$ & -0.325 \\
\hline & & & $(0.317)$ & $(0.331)$ \\
\hline \multirow[t]{2}{*}{ Constant cut7 } & & & -0.0757 & 0.258 \\
\hline & & & $(0.317)$ & $(0.330)$ \\
\hline \multirow[t]{2}{*}{ Constant cut 8} & & & $0.527^{*}$ & $0.862 * * *$ \\
\hline & & & $(0.317)$ & $(0.331)$ \\
\hline \multirow[t]{2}{*}{ Constant cut 9} & & & $1.166^{* * *}$ & $1.501 * * *$ \\
\hline & & & $(0.317)$ & $(0.331)$ \\
\hline \multirow[t]{2}{*}{ Constant cut 10} & & & $1.591 * * *$ & $1.927 * * *$ \\
\hline & & & $(0.318)$ & $(0.332)$ \\
\hline Observations & 2467 & 2467 & 2467 & 2467 \\
\hline
\end{tabular}

\section{References}

Addison, J. T., \& Grosso, J.-L. (1996). Job security provisions and employment: Revised estimates. Industrial Relations: A Journal of Economy and Society, 35(4), 585-603.

Andrews, F. M., \& McKennell, A. C. (1980). Measures of self-reported well-being: Their affective, cognitive, and other components. Social Indicators Research, 8(2), 127-155. 
Baum-Snow, N., \& Neal, D. (2009). Mismeasurement of usual hours worked in the census and ACS. Economics Letters, 102(1), 39-41.

Behrman, J. (1999). Labor markets in developing countries. Handbook of Labor Economics, 3, 2859-2939.

Bertram-Hümmer, V., \& Baliki, G. (2015). The role of visible wealth for deprivation. Social Indicators Research, 124(3), 765-783.

Blattman, C., Fiala, N., \& Martinez, S. (2014). Generating skilled self-employment in developing countries: Experimental evidence from Uganda. The Quarterly Journal of Economics, 129(2), 697-752.

Boccuzzo, G., \& Gianecchini, M. (2015). Measuring young graduates' job quality through a composite indicator. Social Indicators Research, 122(2), 453-478.

Borghans, L., Duckworth, A. L., Heckman, J. J., \& ter Weel, B. (2008). The economics and psychology of personality traits. Journal of Human Resources, 43(4), 972-1059.

Brück, T., Esenaliev, D., Kroeger, A., Kudebayeva, A., Mirkasimov, B., \& Steiner, S. (2014). Household survey data for research on well-being and behavior in Central Asia. Journal of Comparative Economics, 42(3), 819-835.

Brunello, G., \& Schlotter, M. (2011). Non cognitive skills and personality traits: Labour market relevance and their development in education \& training systems (No. IZA Discussion Paper 5743). Bonn.

Caplan, R. D., \& Harrison, R. (1993). Person-environment fit theory: Some history, recent developments, and future directions. Journal of Social Issues, 49(4), 253-275.

Chen, M. A. (2007). Rethinking the informal economy: Linkages with the formal economy and the formal regulatory environment (No. ST/ESA/2007/DWP/46).

Clark, A. (2005). Your money or your life: Changing job quality in OECD countries. British Journal of Industrial Relations, 43(3), 377-400.

Clark, A. (2010). Work, jobs, and well-being across the millennium. In E. Diener, J. F. Helliwell, \& D. Kahneman (Eds.), International differences in well-being (p. 489). Oxford: Oxford University Press.

Clark, A. (2015). What makes a good job? Job quality and job satisfaction. IZA World of Labor (215).

Cramer, J., Hartog, J., Jonker, N., \& Van Praag, C. (2002). Low risk aversion encourages the choice for entrepreneurship: An empirical test of a truism. Journal of Economic Behavior \& Organization, 48(1), 29-36.

Cummins, R. (2000). Personal income and subjective well-being: A review. Journal of Happiness Studies, $1(2), 133-158$.

Dahl, S.-Å., Nesheim, T., \& Olsen, K. M. (2009). Quality of work: Concept and measurement (No. RECWP 05/2009). SSRN Electronic Journal.

Davoine, L., \& Erhel, C. (2006). Monitoring employment quality in Europe: European employment strategy indicators and beyond (No. CES Document 66).

de Jonge, J., Bosma, H., Peter, R., \& Siegrist, J. (2000). Job strain, effort-reward imbalance and employee well-being: A large-scale cross-sectional study. Social Science \& Medicine (1982), 50(9), $1317-1327$.

Decancq, K., \& Lugo, M. A. (2013). Weights in multidimensional indices of wellbeing: An overview. Econometric Reviews, 32(1), 7-34.

Diener, E., \& Biswas-Diener, R. (2002). Will money increase subjective well-being? Social Indicators Research, 57(2), 119-169.

Diener, E., \& Oishi, S. (2000). Money and happiness: Income and subjective well-being across nations. In E. Diener \& E. M. Suh (Eds.), Culture and subjective well-being (pp. 185-218). Cambridge: MIT Press. https://doi.org/10.1186/2193-9039-3-13.

Dolan, P., Peasgood, T., \& White, M. (2008). Do we really know what makes us happy? A review of the economic literature on the factors associated with subjective well-being. Journal of Economic Psychology, 29(1), 94-122. https://doi.org/10.1016/j.joep.2007.09.001.

Drobnič, S., Beham, B., \& Präg, P. (2010). Good job, good life? Working conditions and quality of life in Europe. Social Indicators Research, 99(2), 205-225.

Edmonds, E., \& Pavcnik, N. (2005). Child labor in the global economy. Journal of Economic Perspectives, 19(1), 199-220.

Ekelund, J., Johansson, E., Järvelin, M.-R., \& Lichtermann, D. (2005). Self-employment and risk aversion-Evidence from psychological test data. Labour Economics, 12(5), 649-659.

Farber, H. S. (1998). Are lifetime jobs disappearing? In J. C. Haltiwanger, M. Manser, \& R. H. Topel (Eds.), Labor statistics measurement issues (p. 478). Chicago: University of Chicago Press.

Ferrer-i-Carbonell, A. (2005). Income and well-being: An empirical analysis of the comparison income effect. Journal of Public Economics, 89(5), 997-1019.

Gallie, D. (2009). Employment regimes and the quality of work. Oxford: Oxford University Press. 
Gallie, D. (2013). Economic crisis, quality of work and social integration: The European experience. Oxford: Oxford University Press.

García-Pérez, C., Prieto-Alaiz, M., \& Simón, H. (2017). A new multidimensional approach to measuring precarious employment. Social Indicators Research, 134(2), 437-454.

Gómez-Salcedo, M. S., Galvis-Aponte, L. A., \& Royuela, V. (2017). Quality of work life in Colombia: A multidimensional fuzzy indicator. Social Indicators Research, 130(3), 911-936.

Goos, M., \& Manning, A. (2007). Lousy and lovely jobs: The rising polarization of work in Britain. Review of Economics and Statistics, 89(1), 118-133.

Green, F. (2007). Demanding work: The paradox of job quality in the affluent economy. Princeton: Princeton University Press.

Groves, M. O. (2005). How important is your personality? Labor market returns to personality for women in the US and UK. Journal of Economic Psychology, 26(6), 827-841.

Heckman, J. J. J., Stixrud, J., \& Urzua, S. (2006). The effects of cognitive and noncognitive abilities on labor market outcomes and social behavior. Journal of Labor Economics, 24(3), 411-482.

Houseman, S. (1995). Job growth and the quality of jobs in the U.S. economy. Labour (Special Issue), 93, S124.

Kalleberg, A. L., Reskin, B. F., \& Hudson, K. (2000). Bad jobs in America: Standard and nonstandard employment relations and job quality in the United States. American Sociological Review, 65(2), 256-278.

Leete, L., \& Schor, J. B. (1994). Assessing the time-squeeze hypothesis: Hours worked in the United States, 1969-89. Industrial Relations, 33(1), 25-43.

Leschke, J., Watt, A., \& Finn, M. (2008). Putting a number on job quality: Constructing a European Job Quality Index (No. ETUI-REHS Working Paper No. 2008.03).

McBride, M. (2001). Relative-income effects on subjective well-being in the cross-section. Journal of Economic Behavior \& Organization, 45(3), 251-278.

Meier, S., \& Stutzer, A. (2008). Is volunteering rewarding in itself? Economica, 75(297), 39-59.

Muñoz de Bustillo, R., Fernández-Macías, E., Antón, J.-I., \& Esteve, F. (2011). Measuring more than money: The social economics of job quality. Cheltehham: Edward Elgar.

NSC. (2017). Kyrgyz Republic: Employment and Unemployment in 2016. Bishkek: National Statistical Committee of the Kyrgyz Republic.

Pavot, W., \& Diener, E. (1993). The affective and cognitive context of self-reported measures of subjective well-being. Social Indicators Research, 28(1), 1-20.

Presser, H. B. (1999). Toward a 24-hour economy. Science, 284(5421), 1778-1779.

Ritter, J. A., \& Anker, R. (2002). Good jobs, bad jobs: Workers' evaluations in five countries. International Labour Review, 141(4), 331-358.

Schokkaert, E., Verhofstadt, E., \& Van Ootegem, L. (2009). Measuring job quality and job satisfaction. Working Papers of Faculty of Economics and Business Administration, Ghent University, Belgium. Ghent University.

Schoon, I., Hansson, L., \& Salmela-Aro, K. (2005). Combining work and family life. European Psychologist, 10(4), 309-319.

Siegrist, J. (1996). Adverse health effects of high-effort/low-reward conditions. Journal of Occupational Health Psychology, 1(1), 27-41.

Theorell, T., \& Karasek, R. A. (1996). Current issues relating to psychosocial job strain and cardiovascular disease research. Journal of Occupational Health Psychology, 1(1), 9-26.

Wallace, C., Pichler, F., \& Hayes, B. (2007). First European Quality of Life Survey: Quality of work and life satisfaction.

Wooden, M., Warren, D., \& Drago, R. (2009). Working time mismatch and subjective well-being. British Journal of Industrial Relations, 47(1), 147-179.

World Bank. (2012). World Development Report 2013: Jobs. The World Bank Group.

Yamada, G. (1996). Urban informal employment and self-employment in developing countries: Theory and evidence. Economic Development and Cultural Change, 44(2), 289-314.

Yogo, U. T. (2011). Social network and wage: Evidence from Cameroon. Labour, 25(4), 528-543. 